\title{
New Data from Shovakh Cave and Its Implications for Reconstructing Middle Paleolithic Settlement Patterns in the Amud Drainage, Israel
}

\author{
David E. Friesem ${ }^{1,2}$ - Ariel Malinsky-Buller ${ }^{3}$ - Ravid Ekshtain ${ }^{4}$. \\ Shira Gur-Arieh ${ }^{5,6}$ - Anton Vaks ${ }^{7}$. Norbert Mercier ${ }^{8}$. Maïlys Richard ${ }^{8}$. \\ Gilles Guérin $^{9} \cdot$ Hélène Valladas $^{9}$ • François Auger $^{10}$. Erella Hovers ${ }^{4,11}$
}

Published online: 8 July 2019

(C) The Author(s) 2019

\begin{abstract}
This study presents the geoarchaeological and geochronological aspects of Shovakh Cave and the first comparative context to the nearby Amud Cave ( $500 \mathrm{~m}$ downstream), providing an exceptional opportunity to explore the range of human behaviours within a small geographic area. Sediment samples from two newly excavated areas at the rear and entrance of the cave were analysed using infrared spectroscopy, micromorphology and phytolith analysis and dated through uranium-thorium and luminescence techniques. The rear of the cave shows carnivore activity and low artefact concentrations. It also exhibits a shift in sedimentation from wind-blown deposits to colluviation of terra rossa. Direct dating of the deposits associated with the Middle Palaeolithic (MP) occupation at this area could not be obtained due to the breccia forming at the lower part of the excavation area. However, the later phases of the Middle Palaeolithic occupation at this area gave an age estimate of $45.5 \pm 3.7 \mathrm{ka}$. At the entrance of the cave, there are relatively more residues associated with human use of fire. Post-depositional processes in this area include decalcification of the upper layer, cementation of the lower layer and phosphatisation due to guano decomposition, which indicates that this area was probably roofed. The ages obtained in this area range between $67.5 \pm 5.5$ to $56.2 \pm 5.9 \mathrm{ka}$, overlapping with the occupation time of Amud cave. The evidence from Shovakh Cave presents lower intensity of occupation compared to Amud, indicating variable modes of site use by humans in the Amud drainage during the Late Middle Palaeolithic.
\end{abstract}

Keywords Middle Palaeolithic - Site formation processes · Geoarchaeology · Levant · Amud drainage $\cdot$ Caves

David E. Friesem

df360@cam.ac.uk

Extended author information available on the last page of the article 


\section{Introduction}

Cave sites have traditionally been the focus of research on the Middle Palaeolithic period $(250-50 \mathrm{ka})$ in the southern Levant (Fig. 1) since the early twentieth century, due to their long sequences and the diversity of their archaeological archives, including human remains attributed to both Neanderthals and modern humans. The current research focuses on the late Middle Palaeolithic [MP] cave occupations in the lower Nahal Amud during the Late Pleistocene. Currently, 92 caves and rock shelters are known in the cliffs along the lower Nahal Amud (Ullman et al. 2013), but only the four identified in the original survey (TurvillePetre 1927) contain prehistoric remains (Fig. 2). These four caves (south to north: Emireh, Zuttiyeh, Amud and Shovakh) contain various types of behavioural evidence (lithics, fauna, combustion features and micro-botanical remains, as well as human skeletal remains) (Binford 1966; Garrod 1955; Gisis and Bar-Yosef 1974; Hovers et al. 1991; Suzuki and Takai 1970; Turville-Petre 1927).
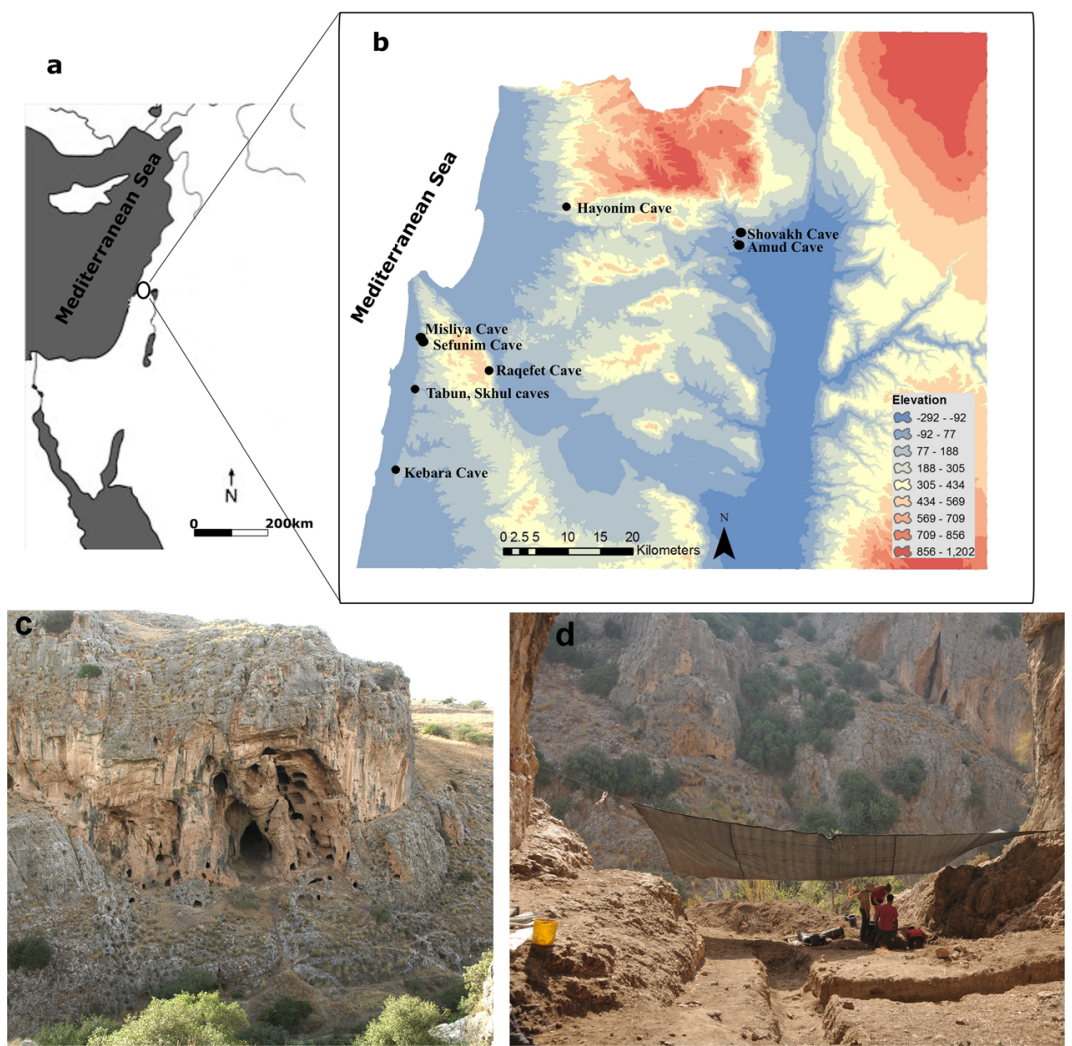

Fig. 1 a A map of the Eastern Mediterranean. b An enlarged map showing the locations of Middle Palaeolithic caves in northern present-day Israel. c A photograph showing the view of Shovakh Cave from the southeast bank of the Amud wadi. d A view towards the entrance from the rear of the cave, showing the excavation of area C (under the shade) and Binford's trenches after cleaning (centre of the photo) 


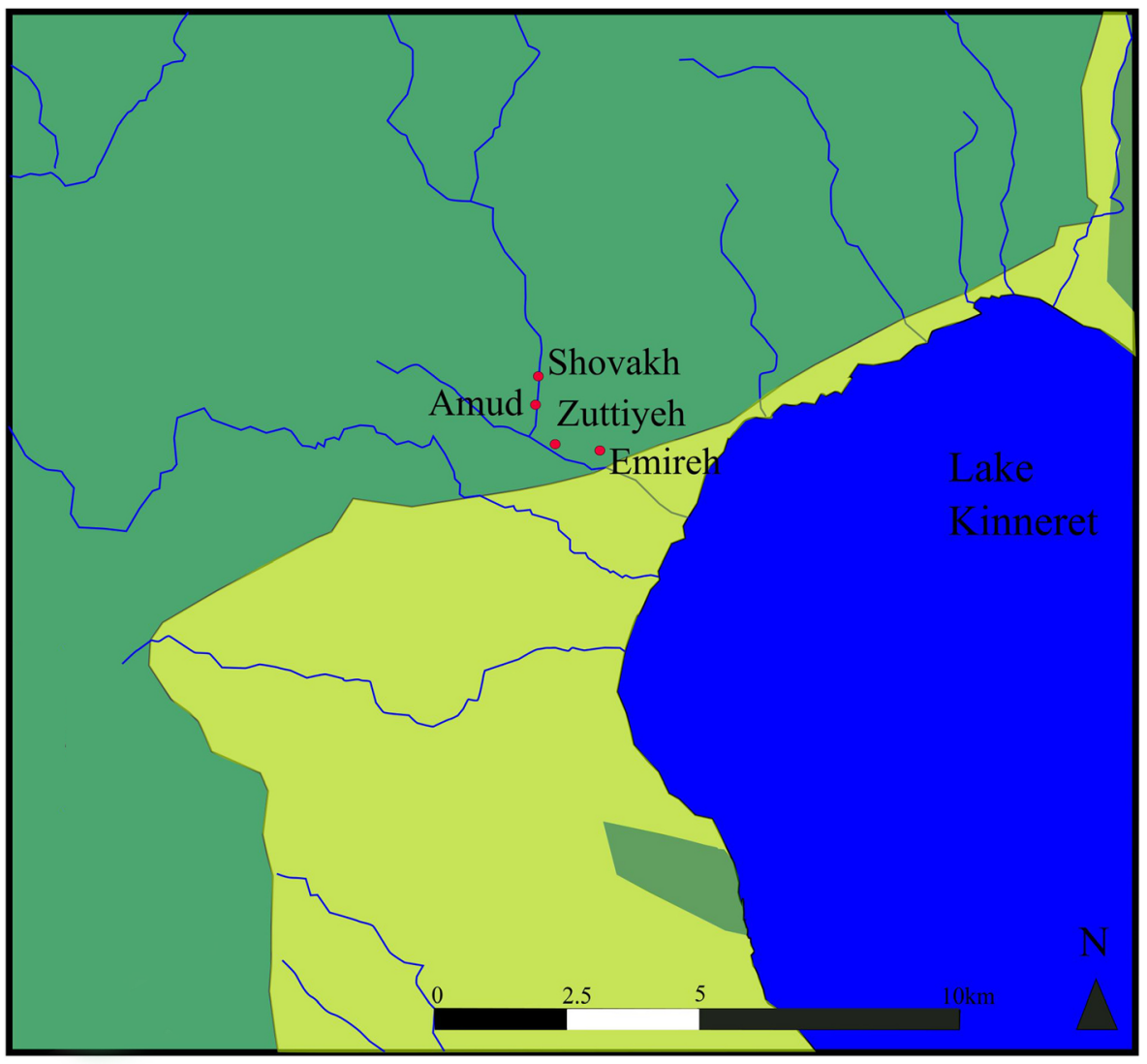

Paleolithic cave site

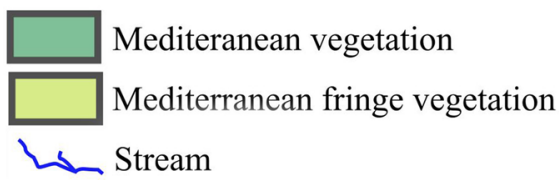

Fig. 2 A map of the Amud drainage, showing the locations of the Palaeolithic cave sites. The phytogeographic zonation are of present day, but based on different sources, these probably reflect past phytogeographic distribution

Palaeolithic occupation in an additional cave is represented only by remnants of breccia that is not amenable to systemic research efforts (Ullman et al. 2013).

In this paper, we focus on Amud and Shovakh caves, with special emphasis on the latter. Both sites were noted by Turville-Petre (1927) but were first excavated only in the 1960s. Amud was since revisited in the 1990s. Each of the sites contains the remains of a single Palaeolithic period, an unusual feature when compared to major cave sites in the Mediterranean zone of the southern Levant (e.g. Tabun, Hayonim, Kebara, Qafzeh, Misliya). Combined with their geographic proximity $(\sim 500 \mathrm{~m}$ apart), this situation provides an exceptional opportunity to 
explore the range of human activities within a given time and landscape. Renewed archaeological and geoarchaeological sampling in Shovakh Cave took place in 2016, within the framework of a more comprehensive project that explores MP hominin behaviours within a geographic micro-region. Our work focused on obtaining data leading to better insights about site chronology, formation processes and behavioural evidence that will enable comparison to Amud Cave within the project's framework. Here, we turn our attention to the geoarchaeology and geochronology of Shovakh Cave.

\section{The Amud Drainage}

The present configuration of the drainage developed over the last 2 million years (Kafri and Heimann 1994; Matmon et al. 1999). The modern channel runs over a short distance of $15 \mathrm{~km}$ from mountains $>1000 \mathrm{~m}$ above sea level (ASL) to lowlying flats $\sim-200 \mathrm{~m}$, cutting through a mixed geological substrate of volcanic and sedimentary rocks. Flowing into the northern section of the Dead Sea Rift, the channel has adjusted to the dynamics of tectonically and climatically induced changes in its erosive base (the paleo-Kinneret, Bartov et al. 2002; Hazan 2003; Hazan et al. 2005; Torfstein et al. 2013), leading to changes in its geometry and immediate landscape (Inbar and Hovers 1999). The channel is located at the edge of the Mediterranean phytogeographical zone, bordering the Irano-Turanian region where there is increased presence of semisteppic plants (Zohary 1973). In combination with the aquatic habitats along the drainage, these create diverse ecological habitats.

The MP occupation of Amud Cave is known through a series of publications that relate to its chronology, site formation processes, human remains, lithics, raw material acquisition and use, macro-and micro-mammals, plant use, hunting territories and spatial organisation of the cave's use (Alperson-Afil and Hovers 2005; Belmaker and Hovers 2011; Ekshtain et al. 2017; Hallin et al. 2012; Hartman et al. 2015; Hovers 2007, 2004; Hovers et al. 2011, 2000, 1995; Kolska Horwitz and Hongo 2008; Krakovsky 2017; Madella et al. 2002; Rabinovich and Hovers 2004; Rak et al. 1994; Rink et al. 2001; Shahack-Gross et al. 2008; Suzuki and Takai 1970; Valladas et al. 1999; Zeigen et al. 2019).

Far less is known from Shovakh Cave (see below), partly due to the fact that it has been heavily disturbed during historical times, which reduced the extent and volume of its Palaeolithic deposits. Binford and Binford's (1966) work on the lithic assemblages suggests broad typo-technological similarities to the Amud assemblages (Malinsky-Buller et al. in prep.), whereas human remains found in both sites were identified as Neanderthals, based on morphology (Hovers et al. 1995; Rak et al. 1994; Trinkaus 1987). Revisiting the site was necessary in order to obtain information that will enable us to better understand its chronology and relate it to the settlement pattern of Amud Cave. In this article, we present the results of geoarchaeological investigations in Shovakh Cave, with the goal of providing new insights into the site's stratigraphic framework and a better understanding of its formation processes. This research is a necessary first step in the overall comparative study of the Amud drainage micro-region. 


\section{Shovakh Cave}

Shovakh Cave (UTM: $32^{\circ} 52^{\prime} 59.5^{\prime \prime} \mathrm{N} 35^{\circ} 30^{\prime} 08.9^{\prime \prime} \mathrm{E}$ ) is a MP site situated in the Levant in today's northern Israel (Fig. 1). The cave is located on the western bank of the Amud stream $\sim 20 \mathrm{~m}$ above the current streambed. It was excavated and published by S. Binford ([1966], using the site's Arabic name Shubabiq) who reported a sequence of MP anthropogenic deposits (ca. 1.2), including hearths and a single Neanderthal tooth (Trinkaus 1987). Archaeological deposits were preserved patchily in the rear and the entrance of the cave. Binford (1966) identified five provenience units based on lithology and lithic artefacts (Figs. 3 and 4). Unit I was classified as "cave earth" containing a mixed assemblage of Holocene and Palaeolithic artefacts. Provenience units II and III are "breccia" (calcite cemented) deposits found in different areas at the rear of the cave, whereas provenience unit IV, underlying unit III, consists of a deposit of soft "cave earth" in the innermost part of the cave, sealed by stalagmite crusts. The various provenience units are not continuous across the cave, but all contained MP lithic assemblages. At the entrance of the cave, sediments were preserved differentially: some of the deposits were brecciated and others include soft sediments (Binford 1966). MP artefacts were obtained from the consolidated sediments at the entrance (Binford's 1966 group V).

The lithic assemblages from the cave were studied mainly from a typological perspective (Binford and Binford 1966; Binford 1966) and were attributed to Bordes' "typical Mousterian". Technological variability between the units (blade frequencies, Levallois frequencies, and ratio between retouched tools to cores) was related to differences in knapping procedures (Binford 1966, pp. 29, 31). Those variations, together with field observations (e.g. absence of visible fireplaces and lack of flaking debris) led Binford to suggest that the rear of the cave was not a living area. The entrance of the cave was suggested to be a food preparation area based on the presence of fireplaces and on lithic characteristics (Binford 1966: Fig. 3, section A-B). Binford and Binford (1966) suggested that the site was a generalised maintenance location rather than a task-specific locale.

Renewed work at Shovakh Cave took place in 2016, aiming to clarify the stratigraphy of the site using sedimentological sampling from Binford's sections (Fig. 3) and obtaining radiometric and luminescence dates for the MP occupations. At the same time, we attempted to enlarge the samples of lithic and fauna from controlled contexts. The retrieved artefacts and bones are being studied together with material from Binford's excavations, focusing on technological patterns, lithic raw material procurement and taxonomic and taphonomic observations on the faunal remains (Malinksy-Buller et al., in prep). The geoarchaeological work we present here provides a necessary context for these findings.

\section{Materials and Methods}

\section{Field Observations and Sampling Strategy}

Two areas were sampled during the 2016 excavation, at the cave rear and at the entrance (areas A and C respectively; Figs. 3 and 4). Sedimentological packages 


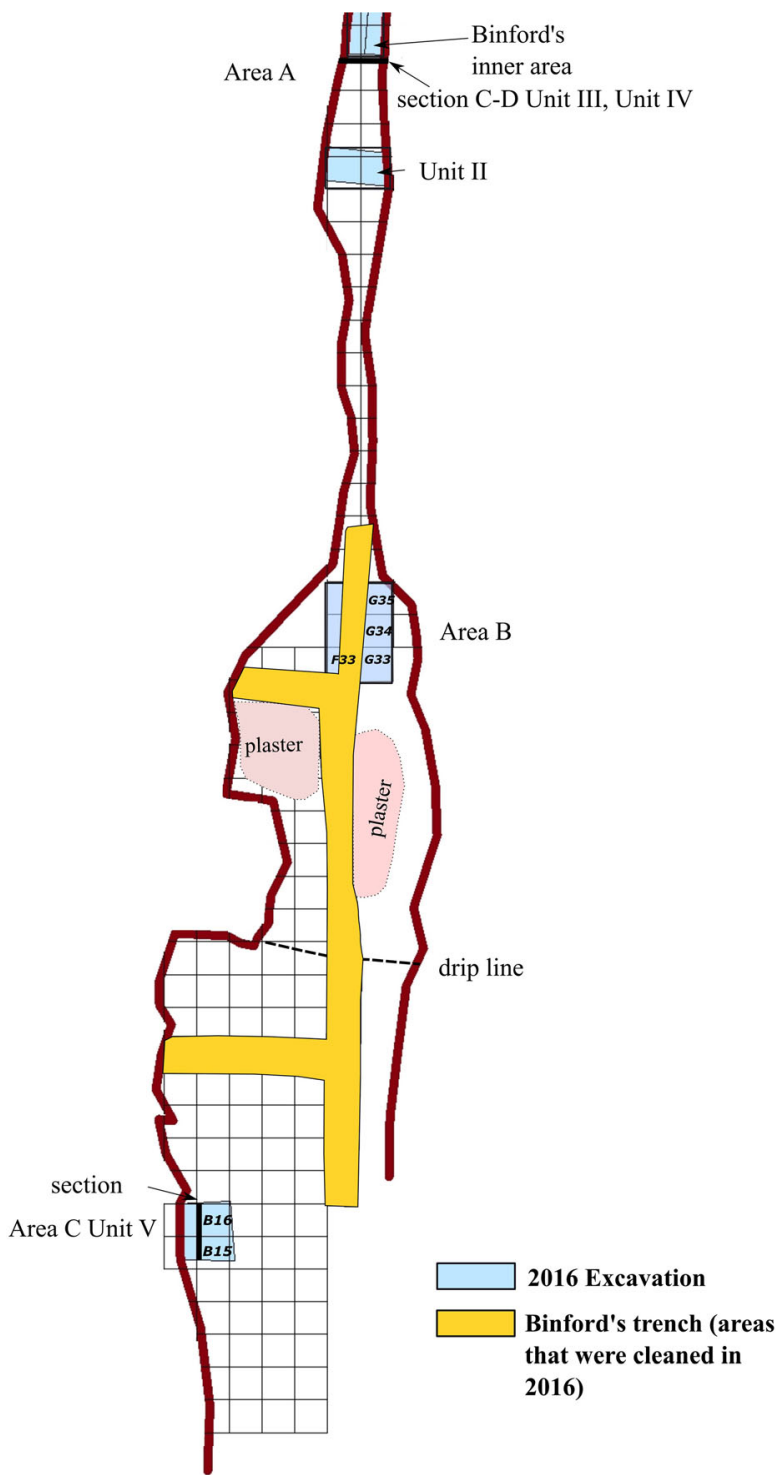

Fig. 3 Plan of Shovakh Cave excavation areas showing Binford's trench areas that were cleaned (in yellow) and the renewed excavation areas (in blue). Each grid square is $1 \times 1 \mathrm{~m}$

were assigned on the basis of field observations and macroscopic properties of the deposits. Area A, in the rear of the cave (sq. F48-G48), was excavated to a depth of $50 \mathrm{~cm}$ and its eastern section sampled (bulk sediment $n=5$; undisturbed sediment blocks $n=2$ ) (Fig. 5a). The topmost part of the profile exhibited few pottery pieces found on the surface of a very soft brown clay-rich sediment. A distinctive sedimentological difference was observed between the upper and lower part of the excavated profile. The upper part, c. $10 \mathrm{~cm}$ below the surface, consisted of a soft dark brown sediment with abundant Mousterian lithic pieces, while the lower part, 




Fig. 4 A cross section of Shovakh Cave showing its topography. The map and attributions are based on Binford's map. Note that the benchmark is an artificial $100 \mathrm{~m}$ baseline set by Binford

c. $40 \mathrm{~cm}$ thick - from $10 \mathrm{~cm}$ below surface to bottom of excavation-was a very hard cemented brown sediment with Mousterian lithic materials and higher density of rock fragments, compared to the upper part of the profile. Area $\mathrm{C}$ is located at the cave's entrance (sq. A15-A16), adjacent to the southern wall where travertine was formed on top of the surface. The area was excavated to a depth of c. $60 \mathrm{~cm}$, revealing Mousterian lithic (and some faunal) remains. In this area the southern and eastern profiles were sampled (bulk sediment $n=5$; sediment blocks $n=2$; rock sample $n=1$ ) (Fig. 5b). The sediments throughout the profile were soft and exhibit shades of grey and brown. No distinctive layering was observed in the field.

\section{Fourier Transform Infrared Spectroscopy}

The bulk sediment $(n=10)$ and rock $(n=1)$ samples collected in the field were divided in the laboratory. The rock sample was divided to separate the core from the rim and sediment attached to the rock. Few bulk sediment samples were subdivided in the laboratory in order to analyse separately the general sediment of the sample and rock fragments or aggregates found in the sample (see Table 1 for full description of all the samples). All the bulk sediment and rock samples $(n=15)$ were analysed using Fourier transform infrared (FTIR) spectroscopy in order to identify the mineral and organic components for each sample. Infrared analysis followed the KBr method (Weiner 2010). Spectra were collected between 4000 and $250 \mathrm{~cm}^{-1}$, at $4-\mathrm{cm}^{-1}$ resolution using a Thermo iS5 spectrometer and interpreted with an internal library of infrared spectra of archaeological materials, following Weiner (2010). A representative portion of each sample $(150 \mathrm{mg})$ was dissolved in hydrochloride acid $(\mathrm{HCl}$ $3 \mathrm{~N}$ ) to assess the percentage of the acid soluble fraction (ASF) in each sample as a measure of the carbonate content. The acid insoluble fractions of the samples $(n=15)$ were measured with FTIR. The dissolution by acid enabled to trace and analyse the clay component and examine whether it has been altered due to burning or not, even in samples where clay was masked by carbonated hydroxyapatite in the pre-treatment FTIR analysis. A total of 30 infrared spectra were collected for this study. 




\section{b}

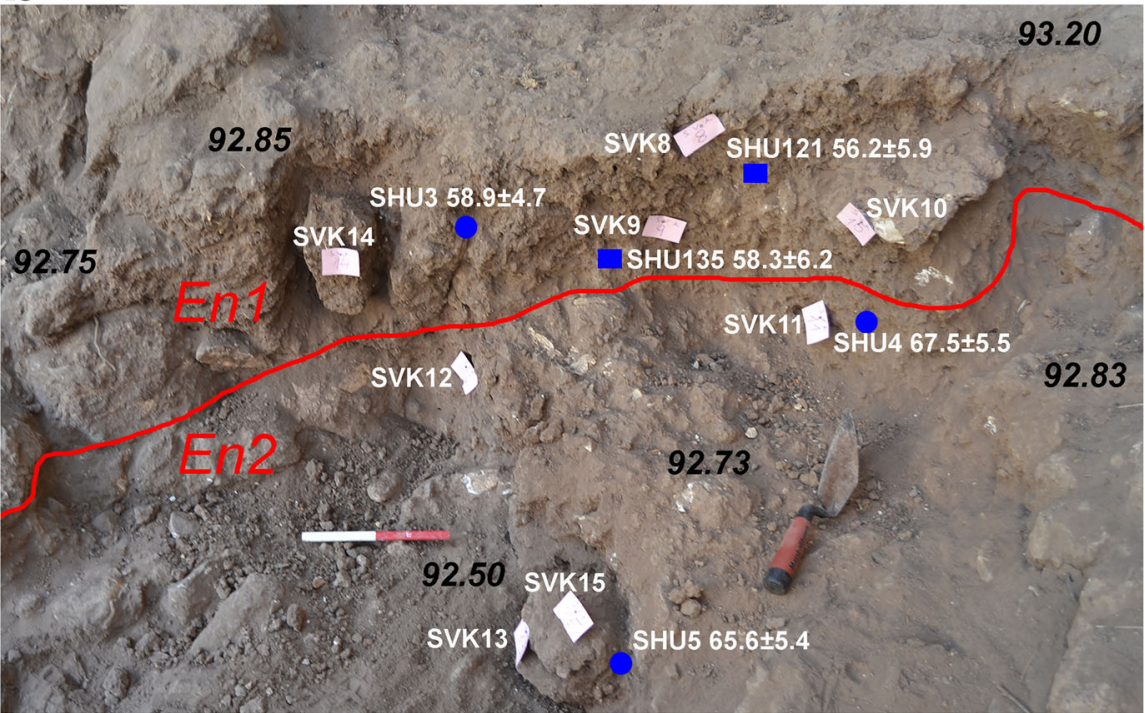

Fig. 5 The profiles of the renewed excavation with elevation (marked in black and in relation to Binford's benchmark, see Fig. 4), sediment sample location, dates (in thousands of years BP) and the borders of the stratigraphic layers (in red). a The eastern profile at the rear of the cave (area A) with the location of block sediment samples (SVK 16-1 and 2) and bulk sediment samples (SVK 16-3 to 7). The location of stalagmite samples (SHOV 3-C and SHOV 3-E) mark by an arrow. The location of OSL samples (SHU1, SHU2) is indicated in blue (note that due to the breccia in the lower part of the profile at the rear of the cave, no date [n.d.] could have been obtained for SHU2). Scale bar is $50 \mathrm{~cm}$. b The southern profile at the entrance of the cave (area C) with the location of bulk sediment samples (SVK 16-8 to 13) and block sediment samples (SVK 16-10, 14 and 15). The location of OSL samples (SHU3 to SHU5) and flint samples dated by TL (SHU121 and SHU135) are marked in blue. Scale bar is $20 \mathrm{~cm}$ 


\section{Phytolith Analysis}

Phytoliths were extracted from bulk sediment samples (Table $2 ; n=9$ ) following the rapid method presented by Katz et al. (2010). Phytolith concentrations were calculated per $1 \mathrm{~g}$ sediment (following Katz et al. 2010), but in order to allow a better comparison with previous studies, and to control for the effect of carbonates dissolution, we also calculated the phytolith concentration in $1 \mathrm{~g}$ of acid insoluble fraction (AIF) (Table 2). Note that our AIF is not directly comparable to that of Albert et al. (1999) or to the one applied by Madella et al. (2002), as we have only removed the carbonates and did not remove the organic material. The samples were scanned using a light microscope (Zeiss Axio) to count individual phytoliths in 30 fields at $\times 400$ magnification. Multi-cell $(\mathrm{MC})$ articulated phytoliths were counted according to the number of single cells inside them to avoid a possible bias, whereby better-preserved samples appear to have lower concentrations than they actually have. Phytolith morphologies were studied at $\times 400$ magnification when at least about 200 phytoliths were identified for each sample and described according to the standard literature (Madella et al. 2005; Mulholland and Rapp 1992a; Piperno 2006).

The main purpose of the phytolith analysis was to provide information on human use of plants in the cave and to compare it to the finds in the nearby Amud Cave. Therefore, we have divided the different phytolith morphologies to taxonomic and anatomic categories similar to the ones applied to the sediments in Amud Cave (Madella et al. 2002) and compared our results to the reference collection prepared by Albert et al. (1999). The first category is that of phytoliths derived from monocotyledonous plants (hereafter monocots), mainly grasses (Poaceae), although other families such as the Cyperaceae (rushes) and Juncaceae (sedges) can also potentially contribute to this category (Fig. 6a-r). The second category is that of phytoliths derived from dicotyledonous plants (hereafter dicots), mostly wood/bark and leaves of woody plants (Fig. 6s-v). The third category includes all the phytoliths that showed abundant signs of weathering, sometimes to the extent that they were unrecognisable (Fig. 6q-r). The fourth category includes phytoliths that could not be assigned to any of the first three categories and were defined as "other". The monocot phytoliths were further divided according to anatomical parts (leaf/stem vs. inflorescence). We also divided the short cell phytoliths from grass epidermis derived from the three Poaceae subfamilies: (1) Pooideae (C3 grasses typical in cool moist climate, Fig. 6a-c); (2) Chloridoideae (C4 grasses typical in dry and hot environments, Fig. 6d-e); (3) Panicoideae (C4 grasses typical in warm and wet environments, Fig. 6f-i) (Barboni et al. 1999; Mulholland and Rapp 1992b; Twiss 1992; Twiss et al. 1969). In addition, the ratio of variable to consistent morphologies (v/c index) was calculated following Albert et al. (1999). This value has been shown to be useful to express the phytolith contribution of dicot wood/bark vs. herbaceous plants in the assemblages. Since wood and bark has been shown to contain up to $30 \%$ of phytoliths derived from grasses (most probably introduced as contamination, Albert et al. 2003), the V/C indexed was normalised to account for that. 
Table 1 List of bulk sediment samples with field description and the results of acid (HCL $1 \mathrm{~N}$ ) treatment (presented as the percentage of acid soluble fraction (ASF\%)) and the major mineral components based on FTIR analysis. $\mathrm{Cl}$, clay; $\mathrm{Ca}$, calcite; $C H A P$, carbonate hydroxylapatite

\begin{tabular}{|c|c|c|c|c|}
\hline Location & Sample & Description & $\mathrm{ASF} \%$ & Minerals \\
\hline \multirow[t]{10}{*}{ Rear of the cave } & SVK 16-3 & \multirow[t]{2}{*}{ Clayish soft sediment } & & $\mathrm{Cl}, \mathrm{Ca}>\mathrm{CHAP}$ \\
\hline & After $\mathrm{HCl}$ & & 69.1 & $\mathrm{Cl}$ \\
\hline & SVK $16-4$ & \multirow[t]{2}{*}{ Hard brown sediment in stony layer } & & $\mathrm{Ca}>\mathrm{Cl}$, CHAP \\
\hline & After $\mathrm{HCl}$ & & 78.7 & $\mathrm{Cl}$ \\
\hline & SVK $16-5$ & \multirow{2}{*}{$\begin{array}{l}\text { Very hard brown clayish } \\
\text { sediment less stones }\end{array}$} & & $\mathrm{Ca}>\mathrm{Cl}$, CHAP \\
\hline & After $\mathrm{HCl}$ & & 83.8 & $\mathrm{Cl}$ \\
\hline & SVK $16-6$ & \multirow{2}{*}{$\begin{array}{l}\text { Clayish sediment with some } \\
\text { stones hard }\end{array}$} & & $\mathrm{Ca}>\mathrm{Cl}$, CHAP \\
\hline & After $\mathrm{HCl}$ & & 88.5 & $\mathrm{Cl}$ \\
\hline & SVK 16-7 & \multirow[t]{2}{*}{ Clayish hard sediment } & & $\mathrm{Ca}>\mathrm{Cl}, \mathrm{CHAP}$ \\
\hline & After $\mathrm{HCl}$ & & 86.6 & $\mathrm{Cl}$ \\
\hline \multirow[t]{20}{*}{ Entrance of the cave } & SVK 16-8a & \multirow[t]{2}{*}{ Brown grey soft sediment } & & $\mathrm{Cl}>>\mathrm{CHAP}, \mathrm{Ca}$ \\
\hline & After $\mathrm{HCl}$ & & 56.2 & $\mathrm{Cl}$ \\
\hline & SVK $16-8 b$ & \multirow{2}{*}{$\begin{array}{l}\text { Layered rock with brown and yellow } \\
\text { laminations (reaction rim fragment) } \\
\text { with sediment attached }\end{array}$} & & CHAP \\
\hline & After $\mathrm{HCl}$ & & 91.7 & $\mathrm{Cl}$ \\
\hline & SVK 16-9 & \multirow[t]{2}{*}{ Grey soft sediment with yellow nodules } & & $\mathrm{Cl}>>\mathrm{CHAP}, \mathrm{Ca}$ \\
\hline & After $\mathrm{HCl}$ & & 66.9 & $\mathrm{Cl}$ \\
\hline & SVK 16-10a & \multirow[t]{2}{*}{ White inner part of rock with reaction rim } & & $\mathrm{CHAP}>>\mathrm{Cl}$ \\
\hline & After $\mathrm{HCl}$ & & 86.7 & $\mathrm{Cl}$ \\
\hline & SVK 16-10b & \multirow[t]{2}{*}{ Black, orange layers of reaction rim } & & CHAP \\
\hline & After $\mathrm{HCl}$ & & 98.7 & $\mathrm{Cl}$ \\
\hline & SVK $16-10 \mathrm{c}$ & \multirow{2}{*}{$\begin{array}{l}\text { Brown hard sediment attached to } \\
\text { reaction rim }\end{array}$} & & $\mathrm{Cl}, \mathrm{CHAP}, \mathrm{Ca}$ \\
\hline & After $\mathrm{HCl}$ & & 64.7 & $\mathrm{Cl}$ \\
\hline & SVK 16-11 & \multirow[t]{2}{*}{ Brown grey sediment } & & $\mathrm{Cl}, \mathrm{CHAP}>\mathrm{Ca}$ \\
\hline & After $\mathrm{HCl}$ & & 68.5 & $\mathrm{Cl}$ \\
\hline & SVK 16-12 & \multirow[t]{2}{*}{ Brown grey sediment } & & $\mathrm{Cl}, \mathrm{CHAP}, \mathrm{Ca}$ \\
\hline & After $\mathrm{HCl}$ & & 69.6 & $\mathrm{Cl}$ \\
\hline & SVK 16-13a & \multirow[t]{2}{*}{ Brown grey sediment } & & $\mathrm{Cl}, \mathrm{CHAP}, \mathrm{Ca}$ \\
\hline & After $\mathrm{HCl}$ & & 58.7 & $\mathrm{Cl}$ \\
\hline & SVK 16-13b & \multirow[t]{2}{*}{ Black hard material } & & CHAP \\
\hline & After $\mathrm{HCl}$ & & 73.2 & $\mathrm{Cl}$ \\
\hline
\end{tabular}

\section{Soil Micromorphology}

Undisturbed monolith sediment blocks $(n=5)$ were sampled using jackets made of plaster of Paris. The blocks were dried in an oven at $30{ }^{\circ} \mathrm{C}$ and then impregnated using a 9:1 mixture of polyester resin with acetone and $1 \% v: v$ MEKP. Pre-cut sample slices $(66 \times 140 \mathrm{~mm})$ were ground to $30-\mu \mathrm{m}$ thickness 


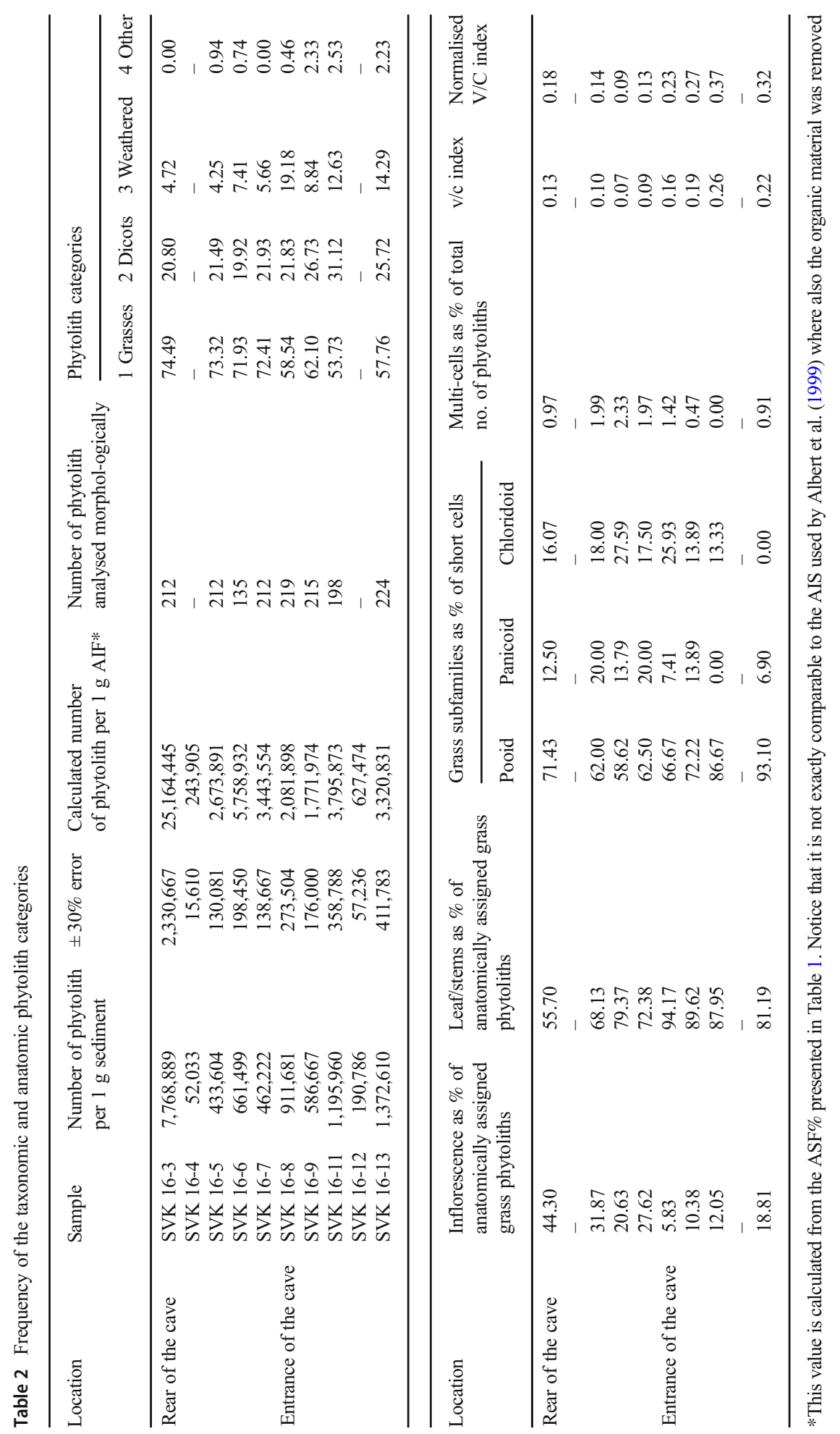



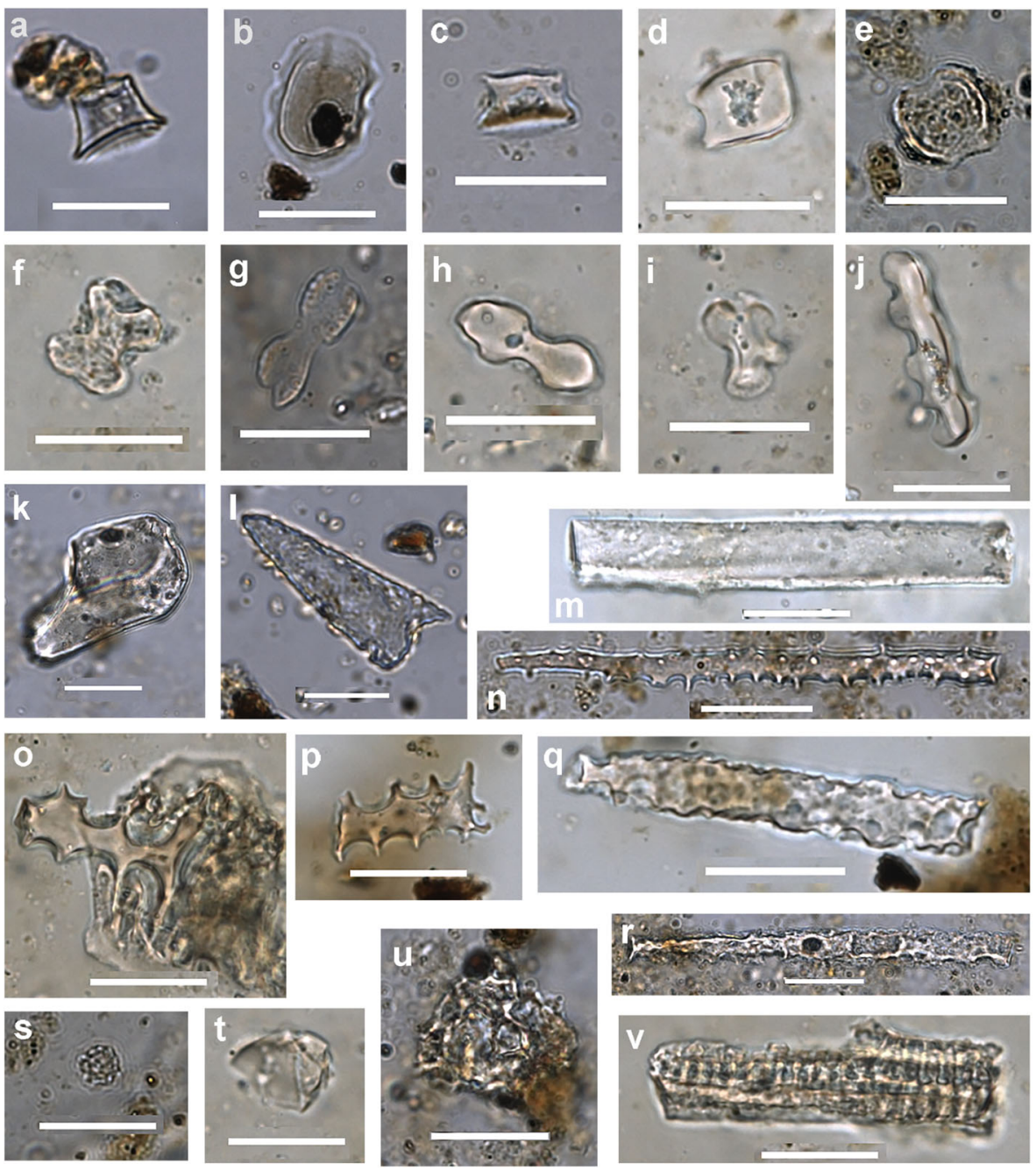

Fig. 6 Microphotographs of representative phytolith morphotypes. a Short cell rondel. b Short cell rondel with a sinuated base. c Short cell rondel with squashed top. d Short cell saddle. e Short cell saddle. f Short cell bilobate with slight flare. g Short cell bilobate with slight flare and long shaft. h Short cell bilobate with round lobes and long shaft. i Short cell cross. j Long cell trapeziform sinuate. k Bulliform cuneiform. I Epidermal appendage prickle. m Parallelepiped elongate psilate. n Long cell verrucate. o Long cell dentritic. p long Cell echinate. q Long cell moderately weathered. r Long cell extremely weathered. s Globular granulate. t Irregular psilate. u Irregular regulate. v Tracheid

thin sections following the method described by Murphy (1986). Thin sections were first studied at a scale of 1:1, scanned using a flatbed scanner and then analysed with a petrographic microscope at magnifications ranging from $\times 4$ to $\times 250$ with plane-polarised light (PPL), cross-polarised light (XPL) and bluelight fluorescence. Micromorphological descriptions employ the terminology of Bullock et al. (1985) and Stoops (2003). 


\section{Uranium-Thorium Dating}

Two specimens of speleothems were taken from area A on both sides of sq. F-G52 (Fig. 3 and Fig. 5a). The specimen SHOV-3 was a $1.5-\mathrm{cm}$ layer of clay-rich carbonate speleothem overlaying other sediment and bedrock on the side of Binford's excavation pit, facing the cave entrance. Specimen SHOV-4 was a thicker formation on the side facing the inner (western) part of the cave and was composed of the following units (Fig. 7): (1) upper layers of clay-rich speleothem carbonate (with sublayers numbered A1-1 to A1-11), $6 \mathrm{~cm}$ thick; (2) layer of rock fragments cemented by clay-rich carbonate, $\sim 3 \mathrm{~cm}$ thick; (3) two thin layers of clay-rich carbonate speleothem, $\sim 1 \mathrm{~cm}$ thick; and (4) bottom layer of carbonate-cemented rock fragments, $4.5-5 \mathrm{~cm}$ thick. The total thickness of SHOV-4 formation was about $15 \mathrm{~cm}$.

Both samples were extracted using hammer and chisel. The specimens were sectioned to expose their internal stratigraphy and to check the layers for secondary porosity, tiny rock fragments and alterations that may indicate possible $\mathrm{U}$ or Th loss. Concentrations of these two elements were measured using a PerkinElmer NexION 300D inductively coupled plasma mass spectrometer (ICP-MS) after addition of Re internal standard with bracketing using Merck-6 standard. For chronology purposes, five samples of 0.03 to $0.1 \mathrm{~g}$ (depending on $\mathrm{U}$ concentrations) were taken from the layers by a Dremel drill. All samples were totally dissolved, with a combination of $7 \mathrm{M} \mathrm{HNO} 3$ and $\mathrm{HF}$, and equilibrated with a mixed ${ }^{229} \mathrm{Th} /{ }^{236} \mathrm{U}$ isotopically clean Harwell spike $\left({ }^{229} \mathrm{Th}>99.99 \% ;{ }^{236} \mathrm{U}=\right.$ $99.97 \%$ ) that was calibrated with gravimetric standards following Henderson et al. (2001). The procedure of extraction of $U$ and Th, their separation and measurement of isotopic ratios by NU Multi Collector-ICP-MS were performed according to the protocol described by Grant et al. ([2012], Supplementary Information, "Materials and Methods").

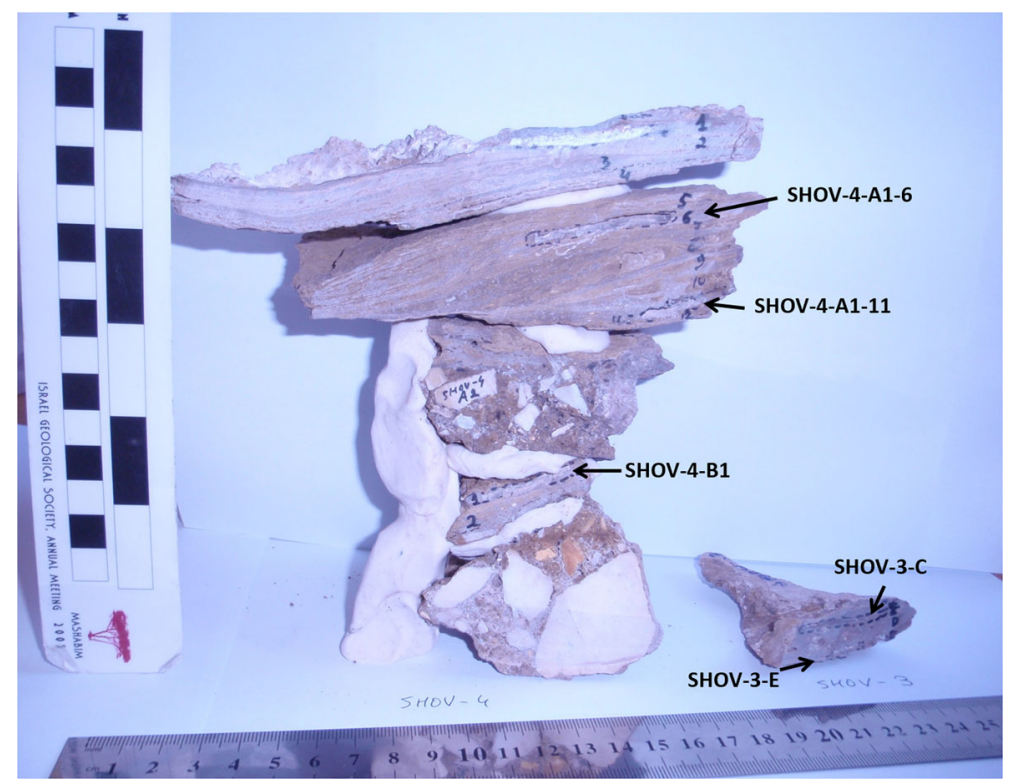

Fig. 7 The speleothems sampled for dating in Shovakh Cave. Note that SHOV-3 is a thin speleothem whereas SHOV-4 presents a complex stratigraphy (for details and measurements, see the text) 


\section{Optically Stimulated Luminescence Dating}

Four sediment samples were dated using optically stimulated luminescence (OSL). One comes from the rear of the cave (area A: SHU1, Fig. 5a) and was taken during the day since almost no light reaches this part of the cave. The three other samples (SHU3, 4 and 5) come from the entrance (area C, Fig. 5b) and were collected at night, after the
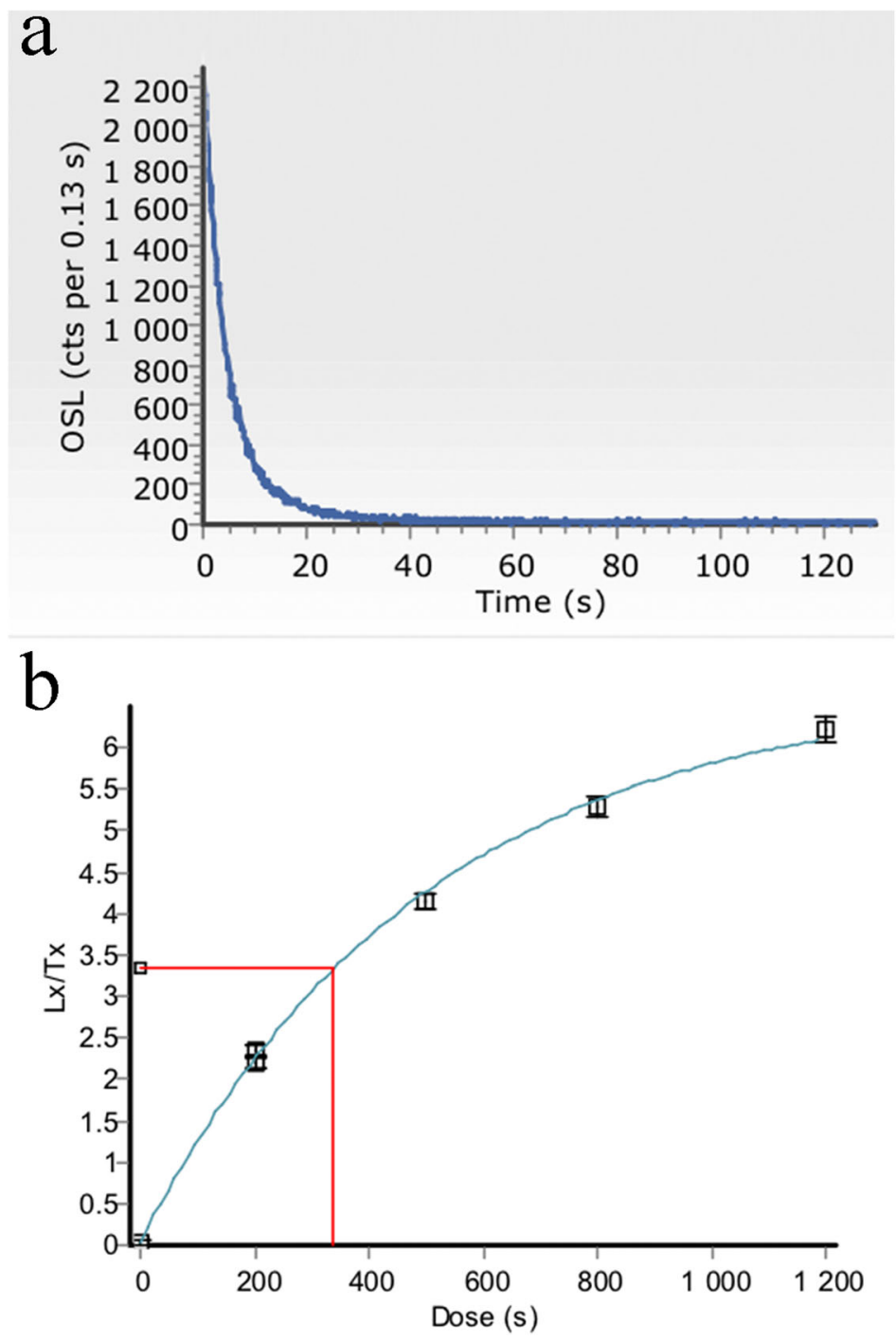

Fig. 8 a Shine-down OSL curve (signal versus stimulation time) of sample SHU1. b Growth curve of normalised OSL signal (regenerated signals normalised to test dose signals). The equivalent dose of this aliquot was determined by interpolating the normalised natural signal onto the growth curve 
surface of the recently exposed profiles was cleaned in order to avoid contamination by newly bleached grains.

Fine grains $(4-11 \mu \mathrm{m})$ were abundant in all these samples (whereas coarse grains were almost totally absent). These fine grains were selected by decantation and purified using a conventional chemical treatment $\left(\mathrm{HCl}\right.$ and $\left.\mathrm{H}_{2} \mathrm{O}_{2}\right)$ to remove carbonates and organic matter, respectively, and $\mathrm{H}_{2} \mathrm{SiF}_{6}$ to dissolve any potential feldspars. The fine-grain fraction exhibited a strong fast component in the OSL signal and the standard single-aliquot regenerative (SAR) dose protocol was applied (Murray and Wintle 2000). Preliminary tests indicated no dependence with the preheat temperature of the natural and regenerated signals (between 200 and $260{ }^{\circ} \mathrm{C}$ ) when a cut-heat of $160{ }^{\circ} \mathrm{C}$ was used for the test dose. Recycling ratio was close to $0.95 \pm 0.05$ and signal recuperation remained low ( $<1.3 \%$ of natural signal). All luminescence measurements were performed with a lexsyg SMART reader (Richter et al. 2015) equipped with green LEDs as the source of stimulation, a combination of UV filters for signal detection, while irradiation was provided with a beta source (dose rate to quartz: $0.18 \mathrm{~Gy} /$ $\mathrm{s})$. All discs (aliquots of $1-\mathrm{cm}$ diameter) used for measurements were entirely covered with fine grains and reproducibility of measurements was excellent. Figure 8 gives an example of OSL signal and growth curve (OSL versus given dose).

$\mathrm{U}$, Th and $\mathrm{K}$ contents of the sediments were determined with high-resolution spectrometry and alpha and beta dose rates calculated using the conversion factors of Guérin et al. (2011), and attenuation factors of Brennan et al. (1991) and Mejdahl (1979). Gamma dosimetry was performed with $\mathrm{Al}_{2} \mathrm{O}_{3}: \mathrm{C}$ dosimeters (Kreutzer et al. 2018) buried for months in the sections.

\section{Thermoluminescence Dating}

Three burnt flints discovered in area $\mathrm{C}$ (Fig. 5b) and showing signs of past heating were selected and prepared for thermoluminescence (TL) measurements. The internal part was extracted using a diamond saw and gently crushed. A fraction of the powder was used for determining the internal $\mathrm{U}$, Th and $\mathrm{K}$ contents of each sample. The $100-160-\mu \mathrm{m}$ fraction was selected by sieving, and after a chemical treatment with $\mathrm{HCl}$ to remove potential carbonates present at the surface of the grains, TL tests were performed with a home-made equipment (Guérin and Lefèvre 2014). Only two out of the three samples exhibited a signal indicating that a sufficiently high temperature had been reached in the past (SHU121 and SHU135).

Using a gamma source, several fractions of the 100-160- $\mu$ m natural powder were irradiated with increasing doses and their signals measured. Each sample showed a TL signal dominated by a peak between 360 and $400{ }^{\circ} \mathrm{C}$ which significantly increased with doses. Paleodoses were calculated as a function of temperature (plateau test) after a supralinearity correction has been made using fractions initially zeroed and artificially irradiated (Fig. 9). 

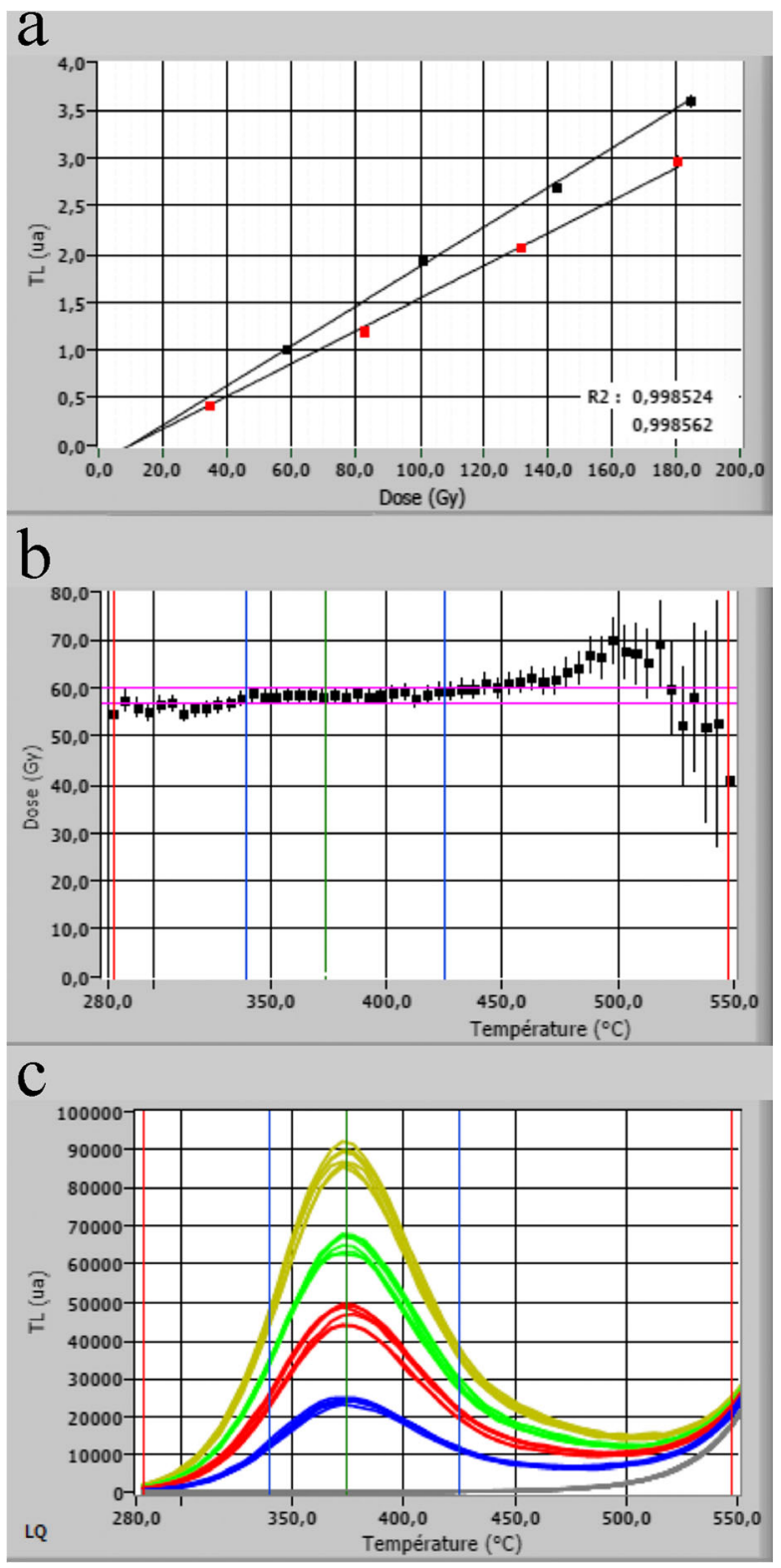

Fig. 9 Sample SHU135: a Growth curves of TL peak with doses (black dots: natural + additional doses; red dots: regenerated doses); b Plateau test (paleodose versus temperature) showing independance of the paleodose with temperature over the TL peak; $\mathbf{c}$ TL glow curves obtained for doses $(0,40,80$ and $120 \mathrm{~Gy})$ given on top of the natural powder 


\section{Results}

\section{Mineralogical Characterisation via FTIR}

Table 1 provides a list of all the bulk sediment and rock samples and the results of their analyses. The sediment from the upper part of the profile in the rear of the cave is composed of soft brown material (SVK 16-3). FTIR analysis showed that this sediment is composed mainly of clay alongside calcite and minor amounts of carbonated hydroxyapatite (CHAP) (Fig. 10a). The middle and lower parts of the profile (SVK 16-4 to 7), which in the field appeared as very hard and cemented brownish sediment, exhibited an increasing amount of calcite with depth as evident from the percentage of the acid soluble fraction (ASF) showing above $80 \mathrm{ASF} \%$, as opposed to $70 \mathrm{ASF} \%$ in the sediment from the top of the profile (Table 1). FTIR analysis of the lower sediments (SVK 16-5 to 7) indicated that calcite is the major mineral component here with clay and CHAP as minor components (Fig. 10b). In none of the samples, before and after

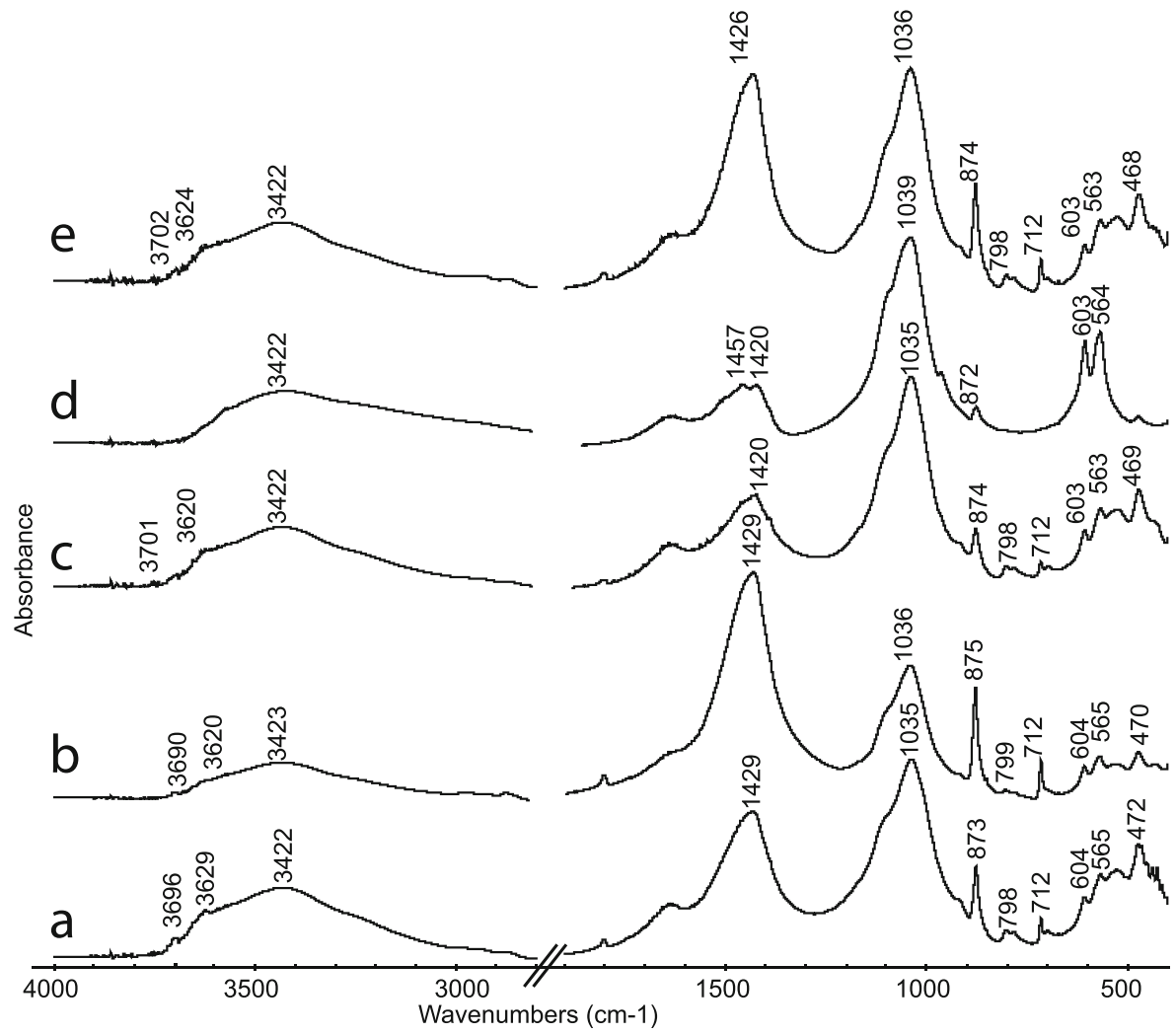

Fig. 10 Representative infrared (FTIR) spectra. a Sediment from the upper part of the profile at the rear of the cave (SVK 16-3) composed mainly of clay $\left(3696,3629,3422,1035,798\right.$ and $472 \mathrm{~cm}^{-1}$ ) and calcite (1429, 873 and $712 \mathrm{~cm}^{-1}$ ) with CHAP as a minor component $\left(604\right.$ and $\left.565 \mathrm{~cm}^{-1}\right)$. b Sediment from the lower part of the profile at the rear of the cave (SVK 16-6) showing similar mineralogical composition to the top sediment but with higher concentration of calcite. $\mathbf{c}$ Sediment from the upper part of the profile at the entrance of the cave (SVK 16-8) composed mainly of clay with calcite and CHAP as minor components. $\mathbf{d}$ A phosphatised limestone rock from the middle part of the profile at the entrance of the cave (SVK 16-10a) showing extensive replacement of calcite with CHAP. e Sediment from the lower part of the profile at the entrance of the cave (SVK 16-12) composed of calcite, CHAP and clay 

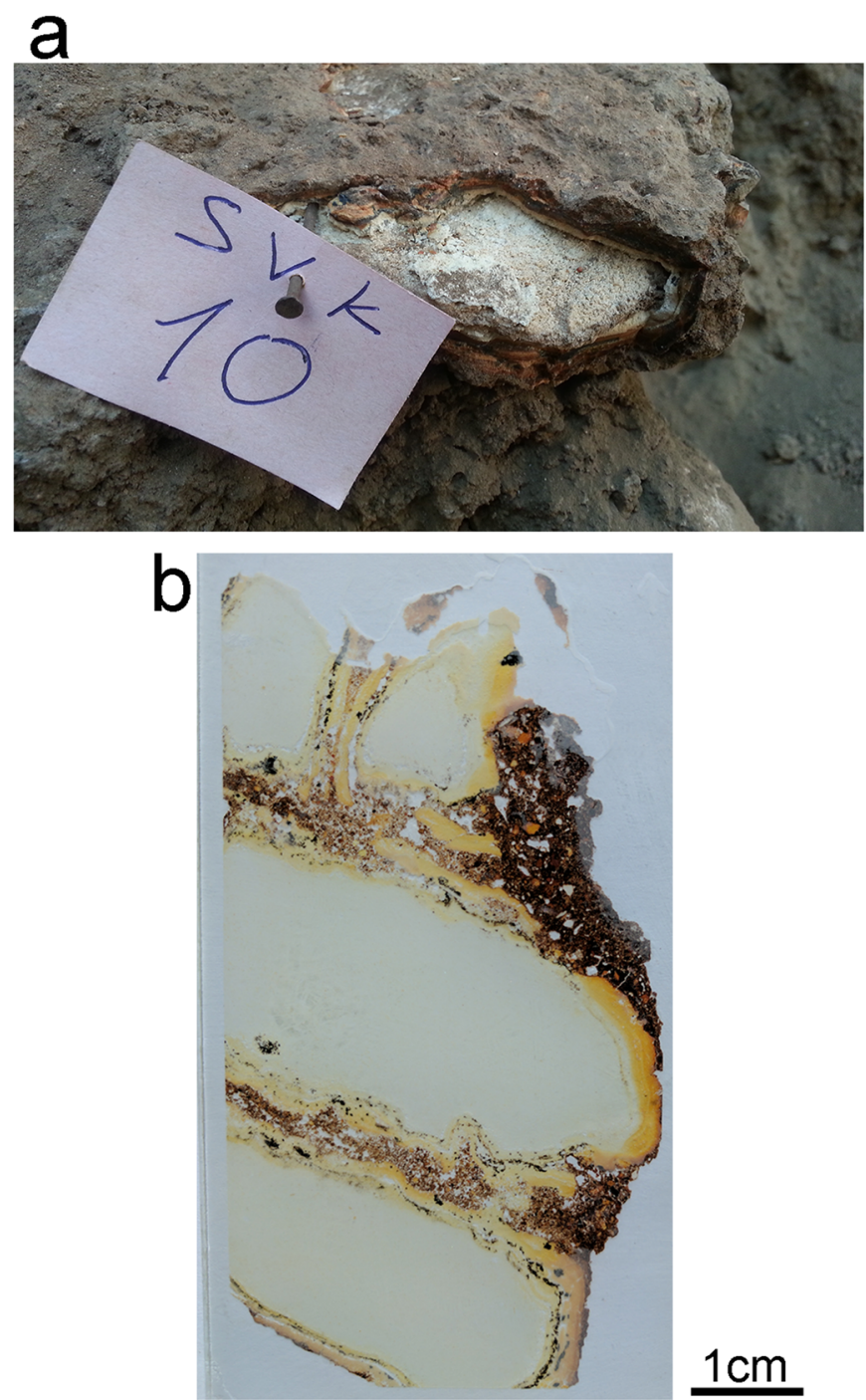

Fig. 11 Phosphatied limestone. a Field photograph showing limestone with a phosphatised reaction rim (SVK 16-10). b Scan of a thin section (SVK 16-15II) made from a limestone showing a phosphatised reaction rim

acid treatment, did the clay component show any indication for alteration due to exposure to elevated temperatures.

The mineralogical analysis of the sediments from the cave's entrance indicated that the samples from the upper part of the profile (SVK 16-8 to 10) slightly differ from the lower ones (SVK 16-11 to 13) in the amount of CHAP and calcite. The samples from the upper part of the profile exhibited clay as the major mineralogical component with minor amounts of CHAP and calcite (Fig. 10c). A limestone fragment (Fig. 11) from the middle part of the profile was subdivided to its core, reaction rim and the sediment attached to the rim (SVK 16-10a, b and c, respectively). FTIR analysis showed that the inner part of the rock as well as its rim are composed almost inclusively of CHAP with very little amount of calcite (Fig. 10d). Analysis of the sediment samples from the 
lower part of the profile in the cave's entrance (SVK 16-11 to 13) showed that they are composed mainly of clay, but as opposed to the sediment of the upper part of the profile, CHAP and calcite are in higher concentrations (Fig. 10e). Overall, the ASF percentage of the sediment at the entrance of the cave seems similar throughout the profile with values between 56 and 73 ASF\% (Table 1). As in the rear part of the cave, the clay showed no signs of alteration due to exposure to elevated temperatures.

\section{Phytolith Analysis}

The concentrations of all the samples analysed are shown in Table 2 and Fig. 12. The top sediment at the rear of the cave (SVK 16-3) yielded the highest concentration of phytoliths with $7.8 \pm 2.3$ million phytoliths per gram sediment ( $\mathrm{M}$ phyt $\mathrm{g} / \mathrm{sed})$. The hard sediment at the middle and lower parts of the profile (SVK 16-4 to 7) showed lower concentrations ranging between 0.7 and $0.05 \mathrm{M}$ phyt $\mathrm{g} / \mathrm{sed}$. The samples collected from the entrance of the cave (SVK 16-8, 9, 11 to 13) presented relatively higher amounts of phytoliths compared to the rear of the cave, excluding the top sediment (SVK 16-3). The sediments from the entrance of the cave showed values between 1.4-0.2 M phyt g/sed. Phytolith preservation appears to be moderate at the entrance to the cave and better at the rear as indicated from the percentage of chemically weathered phytoliths (8.8-19\% vs. $4.3-7.4 \%$ respectively). All samples showed low percentages of MC and low numbers of delicate morphotypes (e.g. dendritic, polyhedrals) and therefore have possibly suffered from mechanical degradation as well.

The frequencies of phytolith morphotypes in all the analysed samples are presented in Table 2 and Fig. 13, excluding two samples (SVK 16-4 and 12) that did not meet the required minimum even after several slides were fully scanned. A third sample (SKV 16-6) that only yielded 135 phytoliths was included in the study and is assumed to be representative of the overall phytolith composition but with lower accuracy (Albert and Weiner 2001). In all of the samples, both phytoliths from monocots and dicots are present (Fig. 13a). The monocots that are the majority of the phytoliths in all of the assemblages can be attributed to grasses, as no indications for the presence of Cyperaceae and Juncaceae were identified. The V/C index of all of the phytolith assemblages $(0.12-0.34)$ is well below the average V/C ratio calculated by Albert et al. (1999) to the common tree species from mount Carmel (5.1), and closer in range to the $\mathrm{V} / \mathrm{C}$ ratio calculated for several grass species (ranging between 0.05-0.15) (Albert et al. 1999), highlighting the contribution of herbaceous plants to the studied assemblages in Shovakh Cave. The sediment at the entrance of the cave shows slightly higher percentages of phytoliths derived from dicots (21.8-31.1\%) when compared to the sediments at the rear of the cave (19.9-21.9\%).

Looking at grass phytoliths that can be assigned to plant anatomical part (Fig. 13b), the percentage of leaf/stem phytoliths (Fig. $6 \mathrm{~g}-\mathrm{j}$ ) is generally higher than the percentage of inflorescence phytoliths (Fig. 61-m) in all of the samples. Yet the percentage of phytoliths derived from grass inflorescence is higher at the rear of the cave with 44-20.6\% when compared with the sediments from the entrance of the cave showing 18.8-5.8\%. The percentage of pooid, chloridoid and panicoid phytolith types were calculated on the sum of short cell phytolith in each sample in order to highlight inter-sample variability. All of the phytolith assemblages from the different sediment samples contained short cells from the three grass subfamilies (Fig. 13c), but the majority of phytoliths are from the pooid type. There is no evidence to the presence of phytoliths derived from the Arecaceae family (palms). 


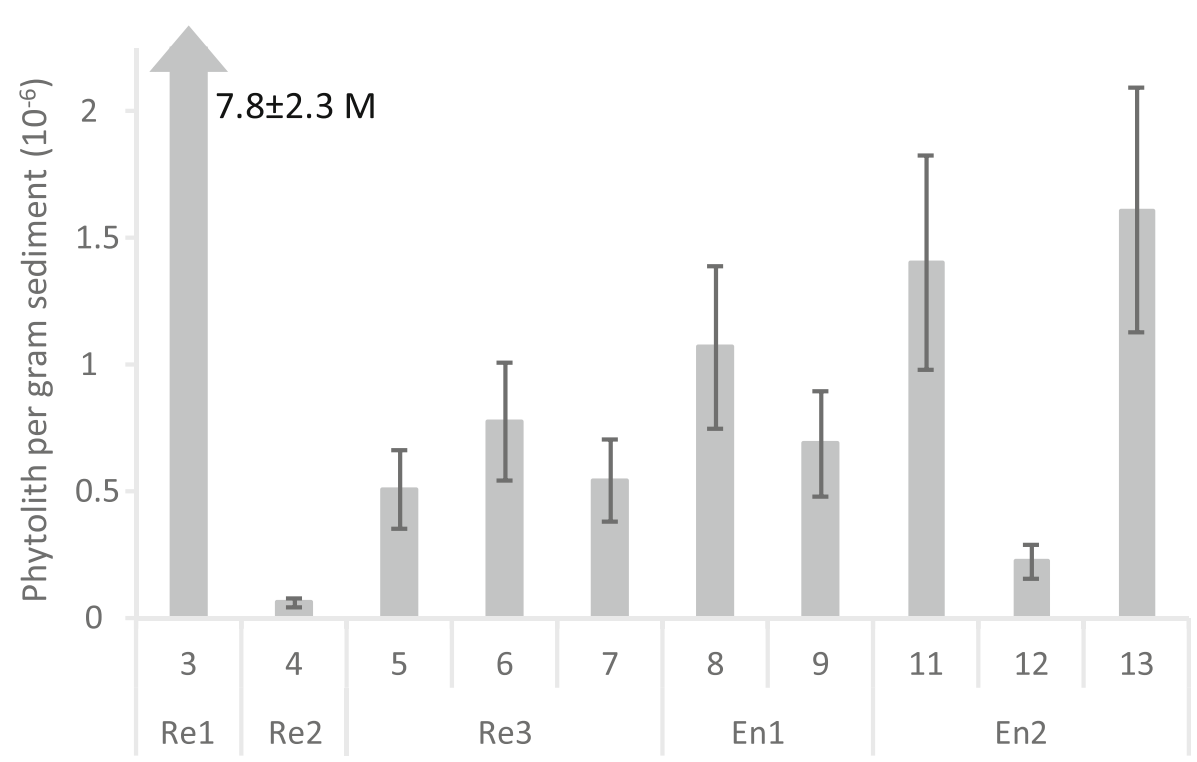

Fig. 12 Phytolith quantification. Chart presenting the concentrations of phytoliths in the sediment samples with error margins of $30 \%$ following Katz et al. (2010)

\section{Micromorphology}

Table 3 provides a list of the sediment block samples and the major micromorphological properties of four microfacies $[\mathrm{MF}]$ identified through microscopic analysis of the thin sections. At the rear of the cave, two distinctive facies were identified (Fig. 14a-c). MF1, associated with the upper part of block SVK 16-1 sampled from the middle of the profile, is composed of relatively loose and clay-rich matrix similar to terra rossa (the type of soil abundant in the plain above the cave), which is partly cemented by secondary calcite (Fig. 14a, c). The sediment also contains charcoal, bone and flint fragments as well as few animal pellets (Fig. 14d, e). A fragment of wall travertine (Fig. 14d) was also identified in MF1 in addition to indications for initial phosphatisation. The latter is evident from a rock with a reaction rim and abundance of phosphatic nodules (Fig. 14f). MF2 (lower part of SVK 16-1 and SVK 16-2) presents a siltier and denser matrix (Fig. 14a-c). The high abundance of phosphatic nodules indicates post-depositional phosphatisation while the increase in calcite provides an indication for re-precipitation of calcite resulting in the cementation of the sediment (Fig. 14g). MF2 contains microcharcoal, flint and bone. The bones show

Fig. 13 Phytolith morphologies. a Chart presenting the percentages of phytolith morphologies identified, according to the four main categories; phytoliths derived from monocot plants (grasses), dicot plants (wood/bark), phytoliths showing signs of weathering and other phytoliths which were not assigned to either of the other categories. b Chart presenting the percentages of grass leaf/stem vs. inflorescence calculated from the total numbers of grass phytoliths that can be anatomically attributed. $\mathbf{c}$ Chart presenting the percentages of phytolith short cells assigned to each of the three grass subfamilies from the sum of short cells; pooid (rondel and trapeziform types), panicoid (bilobate and cross types) and chloridoid (saddle type) 


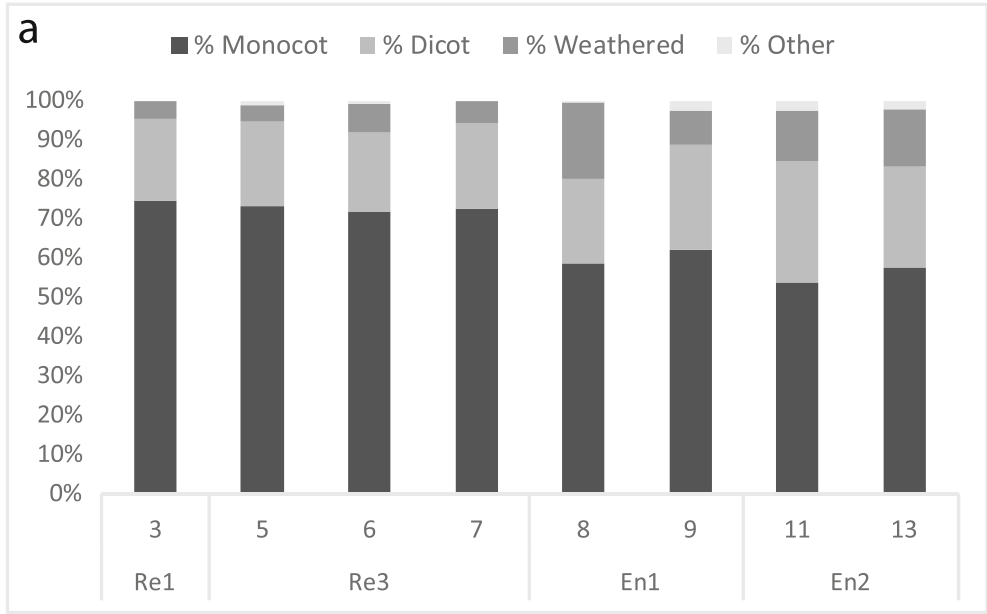

\section{b}

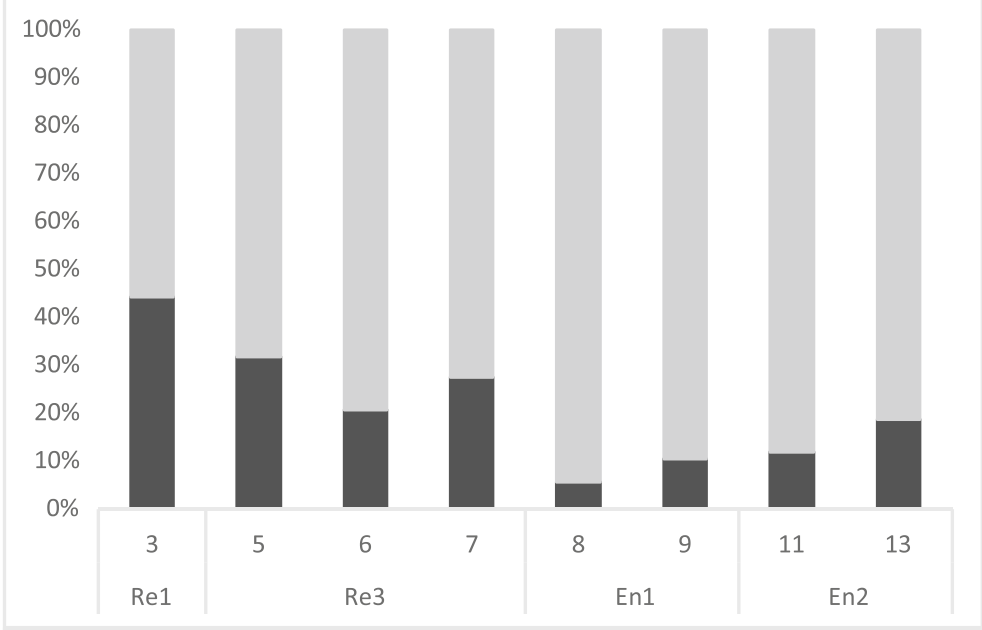

C

$100 \%$

$90 \%$

$80 \%$

$70 \%$

$60 \%$

$50 \%$

$40 \%$

$30 \%$

$20 \%$

$10 \%$

$0 \%$


8

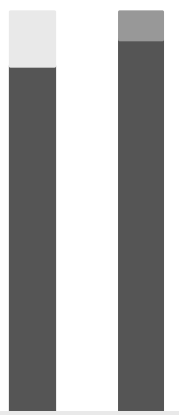

$\operatorname{Re} 1$

Re3

En1

11

13

En2 


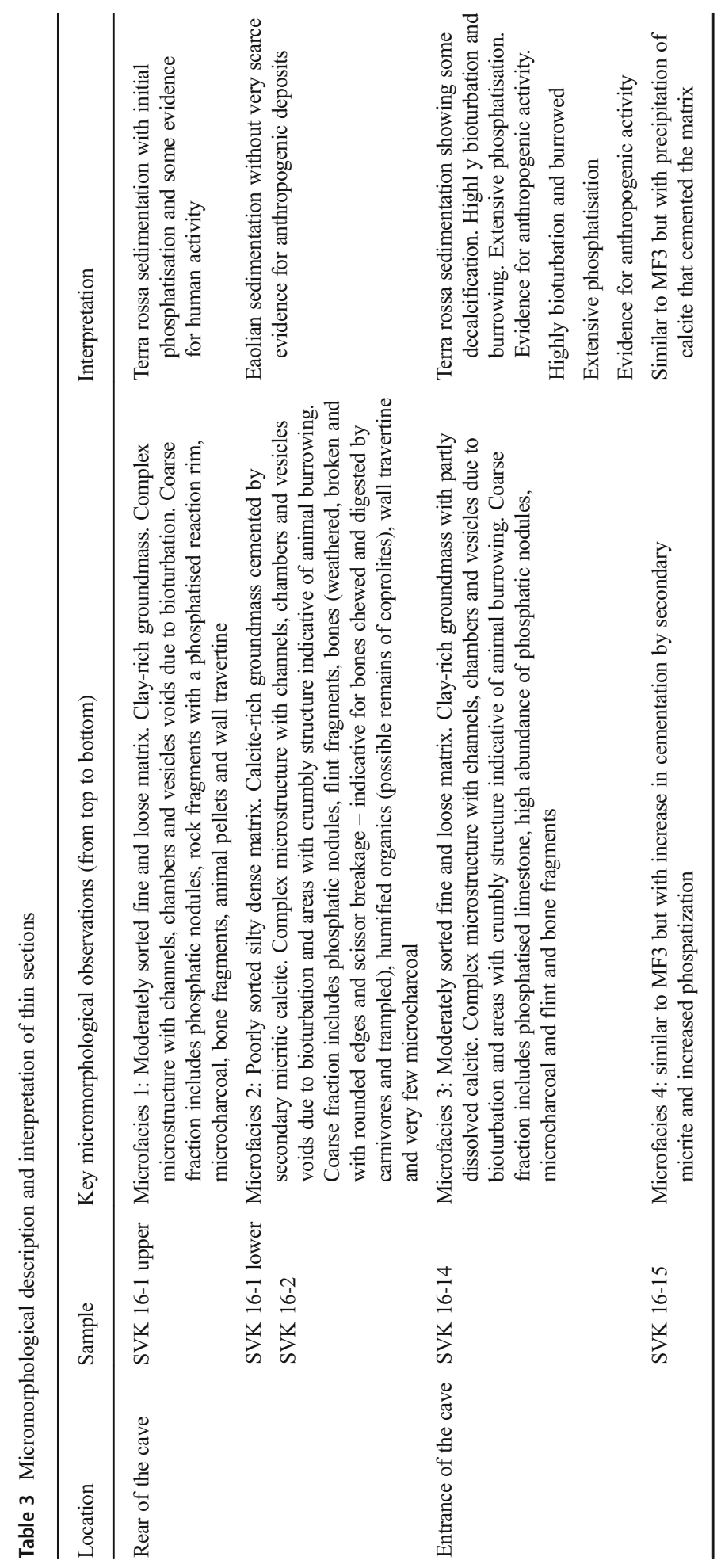





Fig. 14 Micromorphology of sediments from the rear of the cave. a Scan of a thin section from the middle part of the profile (SVK 16-1). Note the two different types of sediments with the upper one (MF1) being looser and clay-rich. b Scan of a thin section from the lower part of the profile (SVK 16-2) presenting a sediment attributed to MF2 with areas of mixed material from MF1 due to burrowing activity [bu]. c Microphotograph showing the contact between MF1 (top) and MF2 (bottom). The left photograph is taken in plane-polarised light (PPL) and the right photograph is taken in cross-polarised light (XPL). d Microphotograph showing MF1 sediment with a piece of charcoal [c], wall travertine [t] and flint [f] fragments embedded in clay-rich matrix cemented by calcite and with abundance of phosphatic nodules. Left photo is in PPL and the right photo is in XPL. e Microphotograph showing MF1 matrix with flint [f] and bone [b] fragments. The bone colour may indicate it is burnt. The left photo is in PPL and the right photo is in XPL. f Microphotograph of MF1 showing a piece of limestone [L] with a phosphatised reaction rim embedded in cemented matrix with phosphatic nodules (appearing as small red-orangey nodules). The left photo is in PPL and the right photo is in XPL. $\mathbf{g}$ Microphotograph of MF2 [2] matrix characterised by extensive cementation by secondary calcite and high abundance of phosphatic nodules. Note the burrow in the middle of the photograph bringing material from MF1 [1]. The left photois in PPL and the right photo is in XPL. h Microphotograph of MF2 matrix showing a large piece of bone [b] with indicative breakage due to chewing by carnivores and trampling (scissors like breakage). The left photo is in PPL and the right photo is in XPL. i Microphotograph of MF2 matrix with the possible remains of a carnivore coprolite showing black humified organic matter $[\mathrm{h}]$ and fragmented bones $[\mathrm{b}$ and arrows] with indicative breakage and weathering due to chewing and digestion by carnivores. The left photo is in PPL and the right photo is in XPL

breakage and weathering patterns indicative of chewing and digestion by carnivores (see Horwitz and Goldberg 1989) associated with concentrations of humified organics (Fig. 14h, i). Due to the poor conditions of preservation, we did not identify intact coprolite remains. However, the concentration of humified organics, associated with bones that show weathering patterns indicative for carnivore digestion, suggest the presence of weathered coprolite remains.

The micromorphological features from the entrance (SVK 16-14 and 15) differ from the ones at the rear (Fig. 15a, b). The sediment of the block sample collected from the upper part of the profile (SVK 16-14) was classified as MF3 showing a matrix indicative of terra rossa sedimentation with a clay-rich groundmass and partial dissolution of calcite, which evinces initial process of decalcification (Fig. 15c). Overall, the sediment seems to be heavily disturbed by burrows and roots (Fig. 15d). While 




Fig. 15 Micromorphology of sediments from the entrance of the cave. a Scan of a thin section from the upper part of the profile (SVK 16-14) showing MF3. Note the phosphatised limestone fragment [L] in the middle of the thin section. b Scan of a thin section from the lower part of the profile (SVK 16-15) showing MF4 with intensive bioturbation and phosphatised limestone fragments. c Microphotograph showing MF3 in high magnification characterised clay-rich groundmass with partly dissolved calcite and high abundance of phosphatic nodules (in red-orangey colour). The left photo is in PPL and the right photo is in XPL. d Microphotograph showing a large area with crumbly structure in MF3 due to burrowing causing mixing and disturbance to the sediment. The left photo is in PPL and the right photo is in XPL. e Microphotograph of MF3 showing a burnt bone fragments [b] with wood ash particles in the bone voids embedded in clay-rich matrix with phosphatic nodules. The left photo is in PPL and the right photo is in XPL. f Microphotograph showing MF4 in high magnification characterised by precipitation of secondary micritic calcite and high abundance of phosphatic nodules. The granular structure may indicate ancient burrowing activity. The left photo is in PPL and the right photo is in XPL. $\mathbf{g}$ Microphotograph of MF4 displaying granular structure indicative of intensive bioturbation. The matrix show a charcoal [c] and a bone fragment [b]. Note that the bone is embedded in a decalcified matrix, possibly as an intrusive feature due to burrowing activity within the sediment. The left photo is in PPL and the right photo is in XPL. h Microphotograph of a limestone from MF4 with a phosphatised reaction rim. The left photo is in PPL and the right photo is in XPL

phosphatic nodules are abundant in MF3, this microfacies also includes various materials indicating human activity such as microcharcoal, fragments of (burnt) bone and flint and some ash (Fig. 15e). The sediment of the block sample collected from the lower part of the profile (SVK 16-15) has been classified as MF4. Although it did not differ significantly from MF3, it did show an increase in the amount of secondary micrite cementing the matrix (Fig. 15f). MF4 contains a similar abundance of human activity residues (Fig. 15g). Limestone fragments from MF4 presented advanced diagenesis and phosphatisation (Fig. 15h).

\section{U-Series Dating}

Five age determinations from the two speleothems in Shovakh Cave are shown in Table 4. Low $\left({ }^{230} \mathrm{Th} /{ }^{232} \mathrm{Th}\right)$ ratios in samples and high concentrations of non-carbonate 


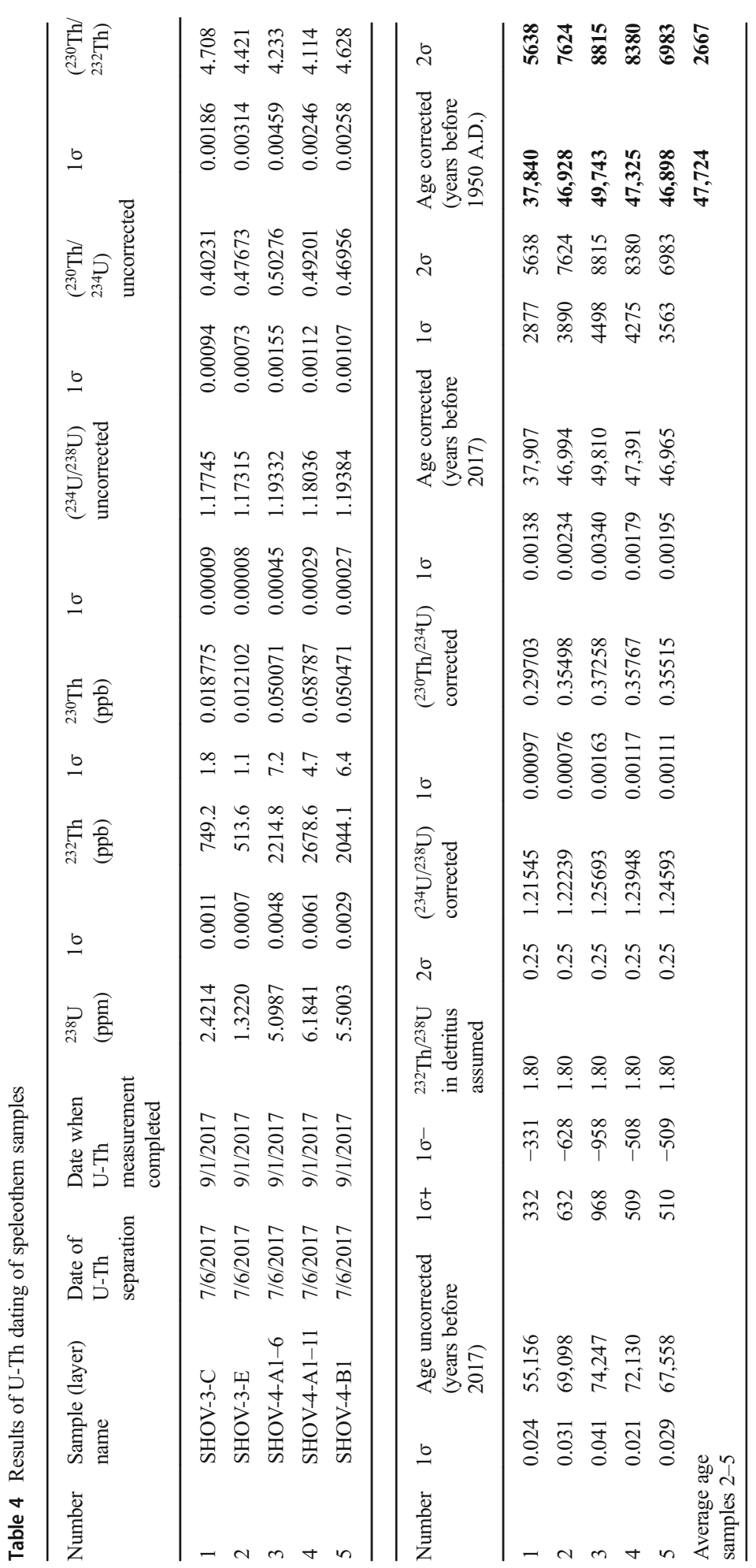


materials rich in Th show that these speleothems contain high concentrations of ${ }^{230} \mathrm{Th}$ from non-radiogenic sources, such as clays, oxides and hydroxides (e.g. Kaufman et al. 1998; Richards and Dorale 2003). This ${ }^{230} \mathrm{Th}$ should be subtracted from the total ${ }^{230} \mathrm{Th}$ in order to obtain the true ages of speleothems. The process of correction for an initial ${ }^{230} \mathrm{Th}$ involves calculation of the amount of ${ }^{230} \mathrm{Th}$ produced by ${ }^{238} \mathrm{U}$ in detrital material of speleothem sample and subtraction of it from total ${ }^{230} \mathrm{Th}$. To perform such calculation, ${ }^{232} \mathrm{Th} /{ }^{238} \mathrm{U}$ atomic ratio in speleothem detrital material is needed. We used the value of $1.80 \pm 0.25$ determined in speleothems in Israeli caves (Grant et al. 2012; Hershkovitz et al. 2015).

The corrected results of SHOV-3 gave two ages: 3c: 37,840 \pm 5638 and 3e: 46,928 \pm 7624 . The second speleothem SHOV-4 yielded three ages: $49,743 \pm 8815,47,325 \pm$ 8380 and $46,898 \pm 6983$, top to bottom (as shown on Fig. 7; the errors are $2 \sigma$ ).

\section{Luminescence Dating}

The radiometric data and OSL and TL ages are reported in Table 5. At the rear of the cave (area A), the sediment sample SHU1 gave the youngest age result $-45.5 \pm 3.7 \mathrm{ka}$. At the entrance of the cave (area C), the two burnt flints, SHU121 and 135, gave similar ages $(56.2 \pm 5.9$ and $58.3 \pm 6.2 \mathrm{ka}$, respectively) which are indistinguishable from the OSL age of SHU3 $(58.9 \pm 4.7 \mathrm{ka})$, taken at about the same elevation. Topographically and stratigraphically lower samples SHU4 and SHU5 provided OSL ages of $67.5 \pm 5.5$ and $65.6 \pm 5.4 \mathrm{ka}$, which are also statistically indistinguishable from one another.

\section{Discussion}

\section{Stratigraphy and Site Formation Processes}

The integration of the different lines of evidence emerging from our analyses allows us to interpret the formation processes of the investigated deposits at Shovakh Cave and to provide a new stratigraphic framework for this site, based on sediment properties and dates. However, since the areas sampled at the rear and entrance of the cave (areas A and $\mathrm{C}$ respectively) were not stratigraphically linked, and we were not able to date the lower part of the section as the rear of the cave, we decided to assign two different stratigraphic systems for the rear ( $\mathrm{Re}$ ) and the entrance (En) of the cave. Formation processes and stratigraphic classification are discussed separately for each area.

\section{The Rear of the Cave}

This part of the site can be divided to three different sedimentological layers (Re1 to Re3; Fig. 5a). The uppermost layer (Re1) seems to differ from the middle and lower sediments due to its exceptional high concentration of phytoliths $(7.8 \pm 2.3 \mathrm{M}$ phyt $\mathrm{g} / \mathrm{sed})$ and the presence of pottery, which suggest that this layer may represent a post-Palaeolithic deposition. Re2 associated with the middle part of the excavated profile has been dated to $45.5 \pm 3.7 \mathrm{ka}$ by OSL (Table 5). Four of five ages provided by U/Th dating of a nearby speleothem (Table 4) range between $46.9 \pm 7.0$ and $49.7 \pm 8.8 \mathrm{ka}$, suggesting an average age of $47.7 \pm 2.7 \mathrm{ka}$ for the time of growth of the speleothem found at the top of Re2. 
Unfortunately, due to the very hard and cemented nature of the sediment of the lower part of the profile, classified as Re3, OSL dating could not be achieved. The difference between Re 2 and Re3 is not only evident by the cementation of the sediments but also in the grain size of the matrix. While Re2 matrix shows a higher component of clay, attributed to terra rossa deposition, the matrix in Re3 is siltier, which may hint to aeolian deposition of silty wind-blown material. Based on other studies, the difference in matrix composition could be tied to changes in deposition patterns resulting from a change in the cave environment and possibly in its configuration (see below).

In Tabun Cave in Mt. Carmel, situated $55 \mathrm{~km}$ to the west of Shovakh Cave, a similar pattern was observed with the deposits from the lower part of the cave being coarser while the ones from the upper part of the cave showed more clay and terra rossa features. In the case of Tabun, this change in the mechanism of sedimentation was interpreted to reflect replacement of wind-blown sedimentation regime with colluvial deposition associated with the opening of the cave's chimney (Albert et al. 1999; Bull and Goldberg 1985; Jelinek et al. 1973). However, in Shovakh Cave we did not identify a chimney. An undiscovered chimney or some fissure in the cave's roof remain as possible scenarios explaining our observations, yet the change in sedimentation regime could also result from a wider environmental change presenting a decrease in wind deposition and increase of sediment transport by low-energy water flows from the plain above the cave. Langgut et al. (2018) argue for a humid interval in the Levant at c. 56$44 \mathrm{ka}$, as also reported by other pollen records and isotopic analyses (Aharonovich et al. 2014; Hartman et al. 2015; Keinan 2016; Langgut et al. 2011). Such an interval associated with an increase in humidity and cooler climate during the last glacial period could potentially result in a change in sedimentation patterns as we report from $\operatorname{Re} 2$, dated by OSL to $45.5 \pm 3.7 \mathrm{ka}$ (Table 5 ). Further study is required in order to provide more details on the deposition patterns at the rear of Shovakh cave and how, if at all, it may link to changes in the cave's and/or the regional environment.

Post-depositional processes in the rear of the cave are characterised by phosphatisation and intense calcite cementation as well as disturbance due to biological activity within the sediments. The cementation in Re3 is associated with the precipitation of micritic calcite acting as a binding material for the sediment's matrix. The increase in calcite concentration is evident from the percentage of ASF (Table 1), FTIR analysis (Fig. 10b) and the micromorphological observations (Table 3 and Fig. 14g).

Phosphatisation and the presence of phosphatic nodules and secondary minerals are well known in Palaeolithic caves (e.g. Goldberg and Nathan 1975; Karkanas et al. 2000, 1999; Miller et al. 2016; Weiner et al. 2002, 1995). This process is derived from decomposition of organic matter (e.g. guano), release of phosphates, and drop in $\mathrm{pH}$ levels, which, given water availability, dissolve carbonates and form secondary phosphatic minerals (Karkanas et al. 2002; Shahack-Gross et al. 2004). The calcite cementation of the deposit would take place at a later stage as part of a more prolonged postdepositional process. The presence of carbonate minerals - in the form of calcite and $\mathrm{CHAP}$ - indicates that the sediment is not very acidic, probably around $\mathrm{pH}$ level 6 . The MP deposits in Hayonim and Kebara caves, in the core Mediterranean ecological zone (30 and $60 \mathrm{~km}$ respectively to the west of Shovakh Cave), present acute diagenesis with more acidic conditions. This resulted in the complete dissolution of carbonate minerals, including of bones (Stiner et al. 2001; Weiner et al. 1995), as well as poor phytolith preservation (Albert et al. 2012, 2003, 2000b). Thus, it appears that taphonomic 


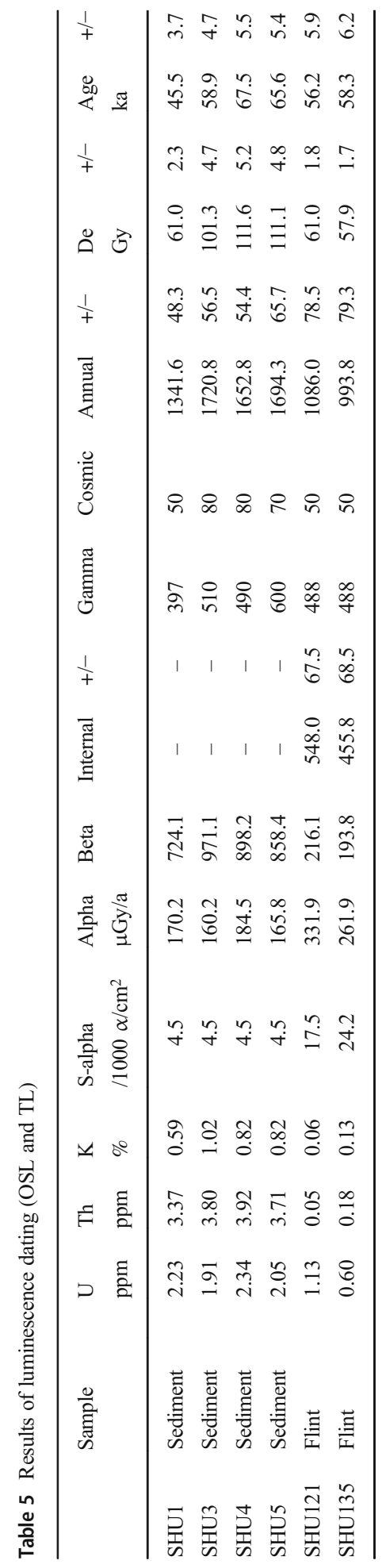


processes in the rear part of Shovakh Cave do show phosphatisation, but not to a degree that obliterated the presence of bones or affected phytolith preservation. The phytolith assemblages show a low to moderate degree of chemical weathering as indicated by the percentages of weathered phytoliths, and a higher level of mechanical weathering as evident from the low percentages of MC and delicate morphotypes.

\section{The Entrance of the Cave}

The profile exposed in the excavation area at the entrance of the cave appeared in the field as one sedimentological package, but based on the mineralogy and dating of the sediments, we suggest it should be divided to two stratigraphic layers (En1 and En2; Fig. 5b), albeit with similar sedimentological characteristics. The depositional process of the entire profile is characterised by colluvial terra rossa sedimentation (i.e. gravitational flow of soil from the plateau above the cave). The sediments are bioturbated, with frequent burrowing. The age estimates of the deposits at the entrance are older than the ones of Re1 and Re2, and possibly overlap with the deposition of Re3. Unfortunately, there are no absolute ages for the latter. While the sediments of En1 and En2 point to a more clay-rich matrix, interpreted as terra rossa sedimentation, Re3 is siltier, possibly due to wind-blown dust sedimentation. The difference could suggest different environmental conditions during different deposition periods. We consider it more likely that this difference is due to location. At the entrance of the cave, terra rossa could be more readily deposited prior to the opening of a chimney or fissures in the cave's walls than it would at the rear of the cave.

The differentiation between the two layers stems from post-depositional processes. The upper part of the excavation area, classified as En1, shows initial decalcification with dissolution of calcite while the lower sediment, classified as En2, exhibits reprecipitation of calcite (Fig. 15c and $\mathrm{f}$, respectively). This process results from the movement of water within the sediments, as reflected also in the formation of travertine on the cave wall in this area. Decalcification is a common post-depositional process and was also reported in the Upper Palaeolithic deposits from the entrance of Sefunim Cave, located $50 \mathrm{~km}$ to the west of Shovakh Cave (Shimelmitz et al. 2018). The presence of limestone fragments in En1 may explain why the carbonate concentrations in En1 and En2 are similar as shown from the ASF percentage (Table 1). As opposed to the case at the entrance of Sefunim Cave, at Shovakh Cave the sediments show extensive phosphatisation as evident from the replacement of calcite with CHAP in the limestone fragments and the high abundance of phosphatic nodules within the sediment.

The form of diagenesis observed at the entrance is similar to the one in the rear of the cave, being typical for roofed areas in caves where guano accumulates in relatively large quantities and later decomposes (Karkanas et al. 2002; Shahack-Gross et al. 2004). As a result, we interpret this part, now being at the very entrance of the cave, to represent an integral part of the roofed cave area, allowing relatively high accumulation of guano, rather than an exterior terrace. While we did not identify in the excavation clear indication for the collapse of the cave's roof, the geoarchaeological evidence implies that during the deposition of the En1 and En2, such a roof may have existed. If so, it collapsed after the MP sediment in this area of the cave was deposited.

The diagenesis of the sediments in the entrance of the cave is moderate. Preservation of carbonates indicates a chemical environment that allows the preservation of bone 
and wood ash. Compared to the rear of the cave, the phytolith assemblage in this area shows a higher degree of chemical weathering (evident by the higher percentages of weathered phytoliths), alongside similar evidence for mechanical weathering indicated from the low percentages of MC and delicate morphotypes. The poorer chemical preservation of the phytoliths can be associated with increased movement of water in this part of the cave. As in the rear of the cave, the low mechanical integrity may be attributed to the high level of bioturbation.

Furthermore, the OSL and TL dating indicate a gap in the deposition of the two layers. Layer En1 dates to $56.2 \pm 5.9$ to $58.9 \pm 4.7$ ka whereas En2 dates to $65.6 \pm 5.4$ to $67.5 \pm 5.5 \mathrm{ka}$. Since the deposition mechanism and post-depositional processes are quite similar between the two layers, it is hard to determine the reason for this gap. While it is possible that the transition between En 1 and En2 is represented by a low rate of sedimentation that puts it beyond dating sampling resolution, it is more likely, given the significant gap in dates, that the transition represents an unconformity in the form of erosion or hiatus in sedimentation. Based on our data, we cannot determine at this stage which of the two scenario is more plausible.

\section{Human Activity at Shovakh Cave}

The interpretation of human behaviour is based in this study on the presence of microscopic materials associated with human activity such as burnt bones, burnt flints, micro-charcoals, ash particles and phytoliths. We have relied on the same microscopic approaches to inform us of depositional contexts and post-depositional processes and to understand their effects on the anthropogenic materials. Thus, the attribution of phytolith concentrations to human activity should be treated with some caution, given the presence of weathered phytoliths and micromorphological observations suggesting intensive burrowing and bioturbation within the sediments. However, based on comparison with regional control samples from the Amud drainage analysed (Madella et al. 2002), where phytolith concentrations did not exceed $0.1 \mathrm{M}$ phyt $\mathrm{g} / \mathrm{sed}$, we argue that the samples with over $0.5 \mathrm{M}$ phyt $\mathrm{g} / \mathrm{sed}$ are most likely to result from human activity.

Excluding the top layer (Re1), interpreted as a post-Palaeolithic deposit, the other two stratigraphic layers at the rear of the cave (Re2 and Re3) exhibit minor amounts of materials that can be directly associated with in situ human activity. Re2, represented by only one sample (SVK 16-4), showed very low numbers of phytoliths. While Re3 showed relatively higher concentrations, the amounts are too low to support suggestions of intensive human occupation (Table 2; Fig. 12). The phytolith assemblages from Re3 exhibit morphologies derived from both dicot plants (wood) and monocot plants (grasses), with the latter being more dominant. The morphologies of grass phytoliths attributed to inflorescence are somewhat higher in comparison to those at the cave entrance. At the nearby Amud Cave, similar values were attributed to the collection of seed-bearing grasses by the site's occupants (Madella et al. 2002). Thus, it is possible that during the deposition of Re3, some ephemeral episodes of human occupation occurred.

Micromorphological observations from Re2 indicate a relative abundance of fire residues that can be associated with human activity (Fig. 14d, e). Adversely, Re3 showed a high abundance of coprolite residues, associated with bones showing breakage and weathering patterns indicative of chewing and digestion by carnivores (Fig. 14h, i). We therefore suggest that during the deposition of Re3, 
this area had been occupied mostly by hyenas alongside very sporadic human presence (for further discussion on division of space between humans and hyenas, see Orbach and Yeshurun 2019).

Binford (1966) reported on the presence of hearths in her excavation at Shovakh Cave. While we did not identify any in situ combustion feature in our limited spatial sampling of the renewed excavation, human use of fire is well documented in our study in the form of microscopic fire residues (e.g. burnt bones and flint, charcoal and ash). The entrance of the cave seems to contain more fire residues than the rear of the cave.

At the entrance of the cave, the abundance of phytoliths, charcoal, bones and flint fragments does not seem to differ significantly between the two stratigraphic layers, En1 and En2. Similar to the rear of the cave, the phytolith assemblages at the entrance exhibit the presence of morphotypes derived both from wood and from grasses, with the latter being the majority. Also, the $\mathrm{V} / \mathrm{C}$ index suggests that herbaceous plants were the main contributors, yet the morphotypes show higher concentrations of phytoliths derived from wood and relatively low concentrations of phytoliths from grass inflorescence. This suggests a higher contribution of phytolith from wood, possibly in the form of ash. The lower percentages of grass inflorescence phytoliths may also be related to the use of grasses as an additional fuel source or for bedding, rather than food. The absence of other phytolith morphotypes attributed to food collection such as palm phytoliths (Madella et al. 2002; Rosen 2003) further supports this interpretation. Grass leaves and stems may have been used for fuel, but also as bedding material as was identified in the sites of Misliya, situated about $55 \mathrm{~km}$ to the west of Shovakh Cave (Weinstein-Evron et al. 2012), Esquilleu cave (Cabanes et al. 2010; Mallol et al. 2010) and in the Middle Stone Age site of Sibudu (Wadley et al. 2011). The use of grasses for bedding was also suggested for Tor Faraj rock shelter based on the distribution of grass phytoliths near the back wall and between the hearths (Henry et al. 2004; Rosen 2003). On the other hand, the low numbers of grass inflorescence may also suggest that the cave was used less during the time that these plants flower and mature (approximately March to May).

The phytolith assemblages in the cave seem to represent human selection rather than their actual distribution in the environment. However, as human selection is also influenced by plant availability in the environment, it is still possible to infer to some extent past environmental conditions from the plants brought to the cave. In all of the cave sediments analysed, the grass short cells are derived from the three Poaceae subfamilies Pooideae, Panicoideae and Chloridoideae (Fig. 13c, Table 2). The majority of the short cells is from the pooid type (61-91\%), which is common in C3 plants adapted to temperate areas (Twiss 1992). Similar phytolith assemblages were reported at Tor Faraj (Rosen 2003) and Kebara Cave (Albert et al. 2012) and are generally in agreement with pollen and isotope analyses showing humid and cool climate conditions in this region during the MP (Aharonovich et al. 2014; Hartman et al. 2015; Keinan 2016; Langgut et al. 2018, 2011). In addition, concentrations of short cells from the chloridoid (5-20\%) and the panicoid (5-18\%) types were found. These are attributed to $\mathrm{C} 4$ plants adapted to warm and dry (chloridoid) and warm and humid (panicoid) conditions (Twiss 1992). This diverse assemblage can suggest that hominin exploited plants from diverse environments around the cave, for instance from the stream at the lower part of the valley and the drier plateau above the cave. A more detailed study of the local plants in the Amud valley is needed to support such interpretation. 
Overall, residues of human activity seem to reflect the use of fire and plants, mostly at the entrance of the cave and to some extent during the deposition of layers Re 2 and Re 3 at the rear of the site, with Re3 exhibiting stronger evidence for carnivore occupation of this part of the cave with possible ephemeral episodes of human occupation.

\section{Comparison with Amud Cave}

This study provides direct evidence for human activity in Shovakh Cave during the Late MP. The dates from Shovakh overlap with human occupation at the nearby Amud Cave, enabling comparison between the two sites within the geographic context of the Amud drainage.

Chronologically, Shovakh Cave presents evidence for human activity spanning the entire time of human occupation at Amud Cave. OSL dates of 67.5 \pm 5.5 and $65.6 \pm$ $5.4 \mathrm{ka}$ from the lower layer at the entrance of Shovakh, En2, overlap with the Amud's earliest archaeological unit, B4, with a TL age estimate of $68.5 \pm 3.4 \mathrm{ka}$ (Valladas et al. 1999). The dates obtained from the upper layer at the entrance of Shovakh, En1 (dated to $58.9 \pm 4.7 \mathrm{ka}$ by OSL and $56.2 \pm 5.9$ and $58.3 \pm 6.2 \mathrm{ka}$ by TL), overlap with the latest MP units in Amud, B2 and B1 (dated to $56.4 \pm 3.5$ and $57.6 \pm 3.7$ ka respectively; Rink et al. 2001; Valladas et al. 1999). In Amud, Unit B3 was interpreted as a sterile layer representing an occupational gap (Hovers 2004). Within this time interval, there seems to be also a gap in the archaeological deposits at Shovakh's entrance, represented by the unconformity in the stratigraphy between En1 and En2.

The rate of sedimentation at Amud Cave seems to be higher than the one we observed in Shovakh Cave, as evident from the sedimentary volume of the anthropogenic stratigraphic units at Amud Cave (each with an average thickness of 50-70 cm). It is possible that due to the configurations of the caves and/or the type, intensity and timing of human activity at each site different deposition processes took place in each case. At Amud, evidence for roof collapse was identified, with fallen blocks intercalated within the MP sediments. The latest phase of such collapse was recognised in sediment of subunit B2, dated to $\sim 55 \mathrm{ka}$ (Hovers 2004; Inbar and Hovers 1999). While further studies are needed in order to determine the formation processes of the unconformity documented in Shovakh Cave, the indication for guano diagenesis at the cave entrance suggests that the area had been previously roofed, implying that a roof collapse has occurred in conjunction with the collapse in Amud c. $55 \mathrm{ka}$.

Unfortunately, no dates could be obtained at this stage from the lower layer at the rear of the cave (Re3). The dates obtained for the overlaying layer, Re2 (47.7 \pm 2.7 and $45.5 \pm$ $3.7 \mathrm{ka}$ by U/Th and OSL respectively) postdate layer En1 as well as Amud's units B1 and B2. The change in sedimentation mechanism between Re1 and Re 2 could be associated with a climatic humid interval ca. $56 \mathrm{ka}$ (Langgut et al. 2018). Whether layer Re3 overlaps temporally with En1 and Amud B4, or with En2 and Amud B1 and B2, will have to be determined by future investigation.

Comparing the evidence for human behaviour from Shovakh Cave (based on the quantity and taxonomy of phytoliths and abundance of fire residues) with that from nearby Amud Cave, it appears that the intensity of human occupation is greater at Amud, with clearer and primary evidence for the use of fire (Madella et al. 2002; Rabinovich and Hovers 2004; Shahack-Gross et al. 2008). All the residues indicative of the use of fire (burnt bones, wood ash, burnt flint fragments, wood phytoliths) are found in Shovakh Cave in lower concentrations compared to Amud Cave, and are localised at the entrance of the cave, and to 
some extent at the middle part of the rear of the cave $(\operatorname{Re} 2)$. The earlier layer at the rear of the cave $(\operatorname{Re} 3)$ presents carnivore coprolites as well as digested and chewed bones, which were not reported in Amud Cave, alongside scarce charcoal and flint fragments. Assuming that human occupation of the cave was not concurrent with carnivores, for example when it was used as a hyena den (e.g. Orbach and Yeshurun 2019), characteristics of layer Re3 strengthen the interpretation of a more episodic hominin use of the rear of the cave during that period.

It is important to bear in mind that a larger area has been excavated and available for analysis at Amud Cave and that our work in Shovakh Cave could be spatially biased. In addition, our quantitative phytolith analysis cannot be compared directly to the results obtained from Amud Cave (Madella et al. 2002) due to differences in extraction methods. None of our samples can be associated with secured contexts such as in situ combustion features as has been suggested in few other MP sites in the region (Albert et al. 2012, 2003, 2000a, 1999; Madella et al. 2002; Rosen 2003). The phytoliths at Shovakh Cave show signs of low to moderate weathering and the sediments present evidence for moderate diagenesis. The range of interpretation of the phytolith record is therefore limited as phytolith assemblages could have been altered. Nevertheless, the phytolith concentrations from Shovakh Cave are generally higher than the control sediments analysed by Madella et al. (2002), except for two samples (SVK 16-4 and 12). Even if we adopt a cautious approach for the interpretation of the phytoliths, it is clear that they were deposited by human activity. Hence, some taxonomical observations can be made to provide important information regarding human use of plants in the site in comparison to the nearby Amud cave.

Similar to Amud Cave and Tor Faraj rock shelter (Henry et al. 2004; Madella et al. 2002; Rosen 2003), the phytolith assemblages at Shovakh Cave indicate a more diverse mode of plant exploitation when compared to other MP caves like Tabun, Kebara, and Hayonim, where studies interpreted plant exploitation mostly as the use of wood for fuel (Albert et al. 2012, 2003, 2000a, 1999) (At Kebara Cave, macrobotanical remains complement the picture, showing diverse plant exploitation including the collection of legumes, acorns and, to lesser extent, cereals, which contributed to the broad-spectrum diet of the cave inhabitants (see Lev et al. (2005)). Phytoliths from grass inflorescence, specifically dendritics, were attributed in Amud, Hayonim and at Tor Faraj to the deliberate collection of mature seed-bearing grasses (Albert et al. 2003; Madella et al. 2002; Rosen 2003). Yet, although grasses were major contributors to the phytolith assemblages at Shovakh Cave, evidence to the gathering of seed-bearing grasses and other edible plants (like palms) is less clear here.

The taphonomic processes occurring within the sediments at Shovakh Cave indicate low acidic conditions, which are favourable for the preservation of phytoliths (Cabanes et al. 2011; Cabanes and Shahack-Gross 2015), yet the assemblages in Shovakh show low to moderate signs of chemical weathering and an even higher degree of mechanical breakage, possibly due to water movement and bioturbation as was identified micromorphologically. Another possible scenario for the mechanical weathering is a low rate of sedimentation resulting in materials being exposed on the surface for prolonged periods and trampled. Rapid burial of materials is a major factor in the preservation of micro-botanical remains (Friesem et al. 2014). In Amud Cave, it has been suggested that the sedimentation rate was relatively high, in particular in units B1 and B2, due to the large amount of ash accumulating at the site as a result of intensive human activity (Madella et al. 2002; Shahack-Gross et al. 2008). Given the richness of phytolith assemblages and the high abundance of fire residues 
at Amud Cave compared to our findings in Shovakh Cave, we suggest that human activity in Shovakh was characterised by lower intensity. Our findings may reflect a more sporadic occupation of the cave at the same time that Amud cave, only $500 \mathrm{~m}$ down the wadi, has been intensively occupied.

\section{Conclusions}

The combination of geoarchaeological and geochronological analyses applied here to the MP deposits of Shovakh Cave results in a reconstruction of a prolonged and complex depositional record for this site. The investigation of deposits from the renewed excavation at Shovakh Cave provides new insights into the site's formation processes, stratigraphy, chronology and human activity. Based on the new dates we present here, the occupation at Shovakh Cave is divided into two phases, the first dated to $67.5 \pm 5.5$ and $65.6 \pm 5.4 \mathrm{ka}$ by OSL, overlapping with Amud's earliest archaeological unit, B4 (Valladas et al. 1999), and the second dated to $58.9 \pm 4.7 \mathrm{ka}$ by OSL and $56.2 \pm 5.9$ and $58.3 \pm 6.2 \mathrm{ka}$ by TL, overlapping the latest MP units in Amud, B2 and B1 (Rink et al. 2001; Valladas et al. 1999). The two localities excavated and sampled for this study were assigned two stratigraphic frameworks (Fig. 5). At the rear of the cave, the lower and earlier layer, Re3, is characterised by wind-blown sedimentation; it is rich in carnivore coprolites and digested bones, with relatively low concentrations of phytoliths, marking low intensity of human activity. The middle layer, Re2, dated to $45.5 \pm 3.7 \mathrm{ka}$ by OSL and $47.7 \pm 2.7 \mathrm{ka}$ in average of U/Th age, indicates a relatively low intensity of human occupation with evidence of fire residues. In addition, this layer also presents a change in deposition patterns with a shift to colluvial terra rossa sedimentation potentially associated with either an opening of a chimney or fissures in the cave wall, or resulting from a wider environmental change during this period. The topmost layer at the rear, Re1, seems to represent a post-Palaeolithic deposition with high concentrations of phytoliths and some pottery shards. At the entrance of the cave, there is a higher concentration of fire residues associated with human use of fire. Post-depositional processes including decalcification of the upper layer, cementation of the lower layer and phosphatisation due to guano decomposition along the entire profile suggesting this area was probably roofed. Based on dating results and differences in carbonate contents, the deposits at the entrance of the cave can be divided into two layers with En1 dated to $56.2 \pm 5.9$ to $58.9 \pm 4.7 \mathrm{ka}$ and En2 to $65.6 \pm 5.4$ to $67.5 \pm 5.5 \mathrm{ka}$. The timing of human occupation of Shovakh Cave is contemporaneous with the nearby Amud Cave, but the evidence of human activity in Shovakh suggests lower intensity of occupation compared to Amud, demonstrating the amplitude of variation of land use by humans during the Late MP within a small geographic area. This study provides an important understanding not only on the formation processes at Shovakh Cave but also sets the ground for a more in-depth exploration of the diversity in human activity and site use during the Late Middle Palaeolithic.

Acknowledgements We are grateful to Masha Krakovsky, Netta Mitki, Nadav Nir, Marion Prevost, Ahiad Ovadia, Micka Ullman and the Schattner family for their help in the field and beyond. We thank Amanda Henry and Charly French for their support and Tonko Rajkovaca for helping with the preparation of the thin sections. Dan Cabanes helped with the preliminary results of the phytholith analyses. We are grateful to Paul Goldberg and the two anonymous reviewers for their comments that helped in improving this article. Permission to excavate in the Nahal Amud Nature Reserve was granted by the Israel Nature and Park Authority. 
Author Contribution A.M-B. R.E. and E.H. excavated the site. D.E.F. collected the geoarchaeological samples, analysed the thin sections and carried out the infrared analysis and the quantification of the phytoliths. S.G-A. analysed the taxonomy of the phytoliths. A.V. collected and analysed the samples for U/Th dating. N.M. collected the samples for OSL and TL dating. N.M. and M.R. analysed the samples for OSL dating and G.G., H.V. and F.A. for TL dating. D.E.F., A.M-B., R.E., S.G-A. and E.H. wrote the paper. A.V. and N.M. contributed to the text, figures and tables for their parts.

Funding Information This study was funded by the Israel Science Foundation (grant no. 1232-2015) to E.H. for the project "Hominins and their environments in Nahal Amud during the Upper Pleistocene" and by grants to R.E. and A.M-B. from the Irene Levy-Sala CARE Foundation and from the Bina and Moshe Stekelis Foundation for Prehistoric Research in Israel. N.M. was financially supported by LaScArBx ANR-10-LABX-52.

Open Access This article is distributed under the terms of the Creative Commons Attribution 4.0 International License (http://creativecommons.org/licenses/by/4.0/), which permits unrestricted use, distribution, and reproduction in any medium, provided you give appropriate credit to the original author(s) and the source, provide a link to the Creative Commons license, and indicate if changes were made.

\section{References}

Aharonovich, S., Sharon, G., \& Weinstein-Evron, M. (2014). Palynological investigations at the Middle Palaeolithic site of Nahal Mahanayeem Outlet, Israel. Quaternary International, 331, 149-166. https://doi.org/10.1016/J.QUAINT.2013.10.043.

Albert, R. M., Bar-Yosef, O., Meignen, L., \& Weiner, S. (2003). Quantitative phytolith study of hearths from the Natufian and middle palaeolithic levels of Hayonim Cave (Galilee, Israel). Journal of Archaeological Science, 30, 461-480.

Albert, R. M., Berna, F., \& Goldberg, P. (2012). Insights on Neanderthal fire use at Kebara Cave (Israel) through high resolution study of prehistoric combustion features: evidence from phytoliths and thin sections. Quaternary International, 247, 278-293. https://doi.org/10.1016/J.QUAINT.2010.10.016.

Albert, R. M., Lavi, O., Estroff, L., Weiner, S., Tsatskin, A., Ronen, A., \& Lev-Yadun, S. (1999). Mode of occupation of Tabun Cave, Mt Carmel, Israel during the Mousterian period: a study of the sediments and Phytoliths. Journal of Archaeological Science, 26, 1249-1260. https://doi.org/10.1006/jasc.1999.0355.

Albert RM, Weiner S (2001) Study of phytoliths in prehistoric ash layers from Kebara and Tabun Caves using a quantitative approach, in: Meunier, J.D., Colin, F. (Eds.), Phytoliths: applications in earth sciences and human history. A.A. Balkema, Lisse, pp. 251-266.

Albert, R. M., Weiner, S., Bar-Yosef, O., \& Meignen, L. (2000a). Phytoliths in the Middle Palaeolithic deposits of Kebara Cave, Mt Carmel, Israel: study of the plant materials used for fuel and other purposes. Journal of Archaeological Science, 27, 931-947. https://doi.org/10.1006/jasc.2000.0507.

Albert, R. M., Wiener, S., Bar-Yosef, O., \& Meignen, L. (2000b). Phytoliths in the Middle Palaeolithic deposits of Kebara Cave, Mt Carmel, Israel: study of the plant materials used for fuel and other purposes. Journal of Archaeological Science, 27, 931-947.

Alperson-Afil, N., \& Hovers, E. (2005). Differential use of space at the Neandertal site of Amud Cave, Israel. Eurasian Prehistory, 3, 3-22.

Barboni, D., Bonnefille, R., Alexandre, A., \& Meunier, J. D. (1999). Phytoliths as paleoenvironmental indicators, West Side Middle Awash Valley, Ethiopia. Palaeogeography Palaeoclimatology Palaeoecology, 152, 87-100. https://doi.org/10.1016/S0031-0182(99)00045-0.

Bartov, Y., Stein, M., Enzel, Y., Agnon, A., \& Reches, Z. (2002). Lake levels and sequence stratigraphy of Lake Lisan, the Late Pleistocene precursor of the Dead Sea. Quaternary Research, 57, 9-21. https://doi. org/10.1006/qres.2001.2284.

Belmaker, M., \& Hovers, E. (2011). Ecological change and the extinction of the Levantine Neanderthals: implications from a diachronic study of micromammals from Amud Cave, Israel. Quaternary Science Reviews, 30, 3196-3209. https://doi.org/10.1016/J.QUASCIREV.2011.08.001.

Binford, L. R., \& Binford, S. R. (1966). A preliminary analysis of functional variability in the Mousterian of Levallois facies. American Anthropologist, 68, 238-295. https://doi.org/10.1525/aa.1966.68.2.02 a001030. 
Binford, S. R. (1966). Me'arat Shovakh (Mugharet esh-Shubbabiq). Israel Exploration Journal, 16, 18-32. https://doi.org/10.2307/27925038.

Brennan, B. J., Lyons, R. G., \& Phillips, S. W. (1991). Attenuation of alpha particle track dose for spherical grains. Journal of Radiation Applications and Instrumentation. Part D. Nuclear Tracks and Radiation Measurements, 18, 249-253. https://doi.org/10.1016/1359-0189(91)90119-3.

Bull, P. A., \& Goldberg, P. (1985). Scanning electron microscope analysis of sediments from Tabun Cave, Mount Carmel, Israel. Journal of Archaeological Science, 12, 177-185. https://doi.org/10.1016/03054403(85)90019-6.

Bullock, P., Fedoroff, N., Jongerius, A., Stoops, G., Tursina, T., 1985. Handbook for soil thin section description., Handbook for soil thin section description. Waine Research, Wolverhampton.

Cabanes, D., Mallol, C., Expósito, I., \& Baena, J. (2010). Phytolith evidence for hearths and beds in the late Mousterian occupations of Esquilleu cave (Cantabria, Spain). Journal of Archaeological Science, 37 , 2947-2957.

Cabanes, D., \& Shahack-Gross, R. (2015). Understanding fossil phytolith preservation: the role of partial dissolution in paleoecology and archaeology. PLoS One, 10, 1-16. https://doi.org/10.1371/journal. pone. 0125532 .

Cabanes, D., Weiner, S., \& Shahack-Gross, R. (2011). Stability of phytoliths in the archaeological record: a dissolution study of modern and fossil phytoliths. Journal of Archaeological Science, 38, 2480-2490. https://doi.org/10.1016/j.jas.2011.05.020.

Ekshtain, R., Ilani, S., Segal, I., \& Hovers, E. (2017). Local and nonlocal procurement of raw material in Amud Cave, Israel: The complex mobility of Late Middle Paleolithic groups. Geoarchaeology, 32, 189214. https://doi.org/10.1002/gea.21585.

Friesem, D. E., Zaidner, Y., \& Shahack-Gross, R. (2014). Formation processes and combustion features at the lower layers of the middle palaeolithic open-air site of Nesher Ramla, Israel. Quaternary International, 331. https://doi.org/10.1016/j.quaint.2013.03.023.

Garrod, D. A. E. (1955). The Mugharet el-Emireh in lower Galilee: type-station of the Emiran industry. The Journal of the Royal Anthropological Institute of Great Britain and Ireland, 85, 141-162. https://doi. org/10.2307/2844188.

Gisis, I., \& Bar-Yosef, O. (1974). New excavation at Zuttieyh Cave, Nahal Amud. Paléorient, 2, 175-180. https://doi.org/10.2307/41489383.

Goldberg, P., \& Nathan, Y. (1975). The phosphate mineralogy of et-Tabun cave, Mount Carmel, Israel. Mineralogical Magazine, 40, 253-258.

Grant, K. M., Rohling, E. J., Bar-Matthews, M., Ayalon, A., Medina-Elizalde, M., Ramsey, C. B., Satow, C., $\&$ Roberts, A. P. (2012). Rapid coupling between ice volume and polar temperature over the past 150,000 years. Nature, 491, 744-747. https://doi.org/10.1038/nature11593.

Guérin, G., \& Lefèvre, J.-C. (2014). A low cost TL-OSL reader dedicated to high temperature studies. Measurement, 49, 26-33. https://doi.org/10.1016/J.MEASUREMENT.2013.11.035.

Guérin, G., Mercier, N., \& Adamiec, G. (2011). Dose-rate conversion factors. Ancient TL, 29, 5-8.

Hallin, K. A., Schoeninger, M. J., \& Schwarcz, H. P. (2012). Paleoclimate during Neandertal and anatomically modern human occupation at Amud and Qafzeh, Israel: the stable isotope data. Journal of Human Evolution, 62, 59-73. https://doi.org/10.1016/J.JHEVOL.2011.09.005.

Hartman, G., Hovers, E., Hublin, J.-J., \& Richards, M. (2015). Isotopic evidence for last glacial climatic impacts on Neanderthal gazelle hunting territories at Amud Cave, Israel. Journal of Human Evolution, 84, 71-82. https://doi.org/10.1016/J.JHEVOL.2015.03.008.

Hazan, N. (2003). Reconstruction of Kinneret Lake levels in the last 40,000 years. Jerusalem: Institute of Earth Sciences.

Hazan, N., Stein, M., Agnon, A., Marco, S., Nadel, D., Negendank, J. F. W., Schwab, M. J., \& Neev, D. (2005). The late Quaternary limnological history of Lake Kinneret (Sea of Galilee), Israel. Quaternary Research, 63, 60-77. https://doi.org/10.1016/j.yqres.2004.09.004.

Henderson, G. M., Slowey, N. C., \& Fleisher, M. Q. (2001). U-Th dating of carbonate platform and slope sediments. Geochimica et Cosmochimica Acta, 65, 2757-2770. https://doi.org/10.1016/S0016-7037(01 )00621-4.

Henry, D. O., Hietala, H. J., Rosen, A. M., Demidenko, Y. E., Usik, V. I., \& Armagan, T. L. (2004). Human behavioral organization in the Middle Paleolithic: were Neanderthals different? American Anthropologist, 106, 17-31. https://doi.org/10.1525/aa.2004.106.1.17.

Hershkovitz, I., Marder, O., Ayalon, A., Bar-Matthews, M., Yasur, G., Boaretto, E., Caracuta, V., Alex, B., Frumkin, A., Goder-Goldberger, M., Gunz, P., Holloway, R. L., Latimer, B., Lavi, R., Matthews, A., Slon, V., Mayer, D. B.-Y., Berna, F., Bar-Oz, G., Yeshurun, R., May, H., Hans, M. G., Weber, G. W., \& Barzilai, 
O. (2015). Levantine cranium from Manot Cave (Israel) foreshadows the first European modern humans. Nature, 520, 216-219. https://doi.org/10.1038/nature14134.

Horwitz, L. K., \& Goldberg, P. (1989). A study of Pleistocene and Holocene hyaena coprolites. Journal of Archaeological Science, 16, 71-94. https://doi.org/10.1016/0305-4403(89)90057-5.

Hovers, E. (2007). The many faces of cores-on-flakes: a perspective from the Levantine Mousterian, in: McPherron, S.P. (Ed.), Cores or tools? Alternative approaches to stone tool analysis. Cambridge Scholars Press, Camabridge, pp. 42-74.

Hovers, E. (2004). Cultural ecology at the Neandertal site of Amud Cave, Israel, in: Derevianko, A.P., Nokhrina, T.I. (Eds.), Arkheologiya i Paleoekologiya Evrasii [Archaeology and Paleoecology of Eurasia]. Institute of Archaeology and Ethnography SB RAS Press, Novosibirsk, pp. 218-231.

Hovers, E. (1998). The lithic assemblages of Amud Cave: implications for understanding the end of the Mousterian in the Levant, in: Akazawa, T., Aokin, K., Bar-Yosef, O. (Eds.), Neanderthals and modern humans in western Asia. Plenum Press, New - York, pp. 143-163.

Hovers, E., Kimbel, W. H., \& Rak, Y. (2000). News and views the Amud 7 skeleton - still a burial. Response to Gargett. Journal of Human Evolution, 39, 253-260.

Hovers, E., Malinsky-Buller, A., Goder-Goldberger, M., Ekshtain, R. (2011). Capturing a moment: identifying short-lived activity locations in Amud Cave, Israel, in: Le Tensorer, J.-M., Jagher, R., Otte, M. (Eds.), The Lower and Middle Palaeolithic in the Middle East and neighbouring regions Proceedings of the Basel symposium (May 8-10 2008) ERAUL 126. University of Liège Press, Liège, pp. 101-114. https://doi. org/10.13140/2.1.2004.4809

Hovers, E., Rak, Y., \& Kimbel, W. H. (1991). Amud Cave - 1991 season. Journal of the Israel Prehistoric Society, 24, 152-157. https://doi.org/10.2307/23373364.

Hovers, E., Rak, Y., Lavi, R., \& Kimbel, W. H. (1995). Hominid remains from Amud Cave in the context of the Levantine Middle Paleolithic. Paléorient, 21, 47-61. https://doi.org/10.2307/41492632.

Inbar, M., \& Hovers, E. (1999). The morphological development of the lower Amud River in the Upper Pleistocene. Horizons in Geography, 50, 27-38. https://doi.org/10.2307/23703866.

Jelinek, A. J., Farrand, W. R., Haas, G., Horowitz, A., \& Goldberg, P. (1973). New excavations at the Tabun cave, Mount Carmel, Israel, 1967-1972: a preliminary report. Paléorient. https://doi.org/10.2307 141489710.

Kafri, U., \& Heimann, A. (1994). Reversal of the palaeodrainage system in the sea of Galilee area as an indicator of the formation timing of the Dead Sea rift valley base level in northern Israel. Palaeogeography Palaeoclimatology Palaeoecology, 109, 101-109. https://doi.org/10.1016/0031-0182 (94)90120-1.

Karkanas, P., Bar-Yosef, O., Goldberg, P., \& Weiner, S. (2000). Diagenesis in prehistoric caves: The use of minerals that form in situ to assess the completeness of the archaeological record. Journal of Archaeological Science, 27, 915-929. https://doi.org/10.1006/jasc.1999.0506.

Karkanas, P., Kyparissi-Apostolika, N., Bar-Yosef, O., \& Weiner, S. (1999). Mineral assemblages in Theopetra, Greece: a framework for understanding diagenesis in a prehistoric cave. Journal of Archaeological Science, 26, 1171-1180. https://doi.org/10.1006/JASC.1998.0354.

Karkanas, P., Rigaud, J.-P., Simek, J. F., Albert, R. M., \& Weiner, S. (2002). Ash bones and guano: a study of the minerals and Phytoliths in the sediments of Grotte XVI, Dordogne, France. Journal of Archaeological Science, 29, 721-732. 10.1006.

Katz, O., Cabanes, D., Weiner, S., Maeir, A. M., Boaretto, E., \& Shahack-Gross, R. (2010). Rapid phytolith extraction for analysis of phytolith concentrations and assemblages during an excavation: an application at Tell es-Safi/Gath, Israel. Journal of Archaeological Science, 37, 1557-1563. https://doi.org/10.1006 /jasc.2001.0742.

Kaufman, A., Wasserburg, G. J., Porcelli, D., Bar-Matthews, M., Ayalon, A., \& Halicz, L. (1998). U-Th isotope systematics from the Soreq cave, Israel and climatic correlations. Earth and Planetary Science Letters, 156, 141-155. https://doi.org/10.1016/S0012-821X(98)00002-8.

Keinan, J. (2016). Paleo-environment of the northern Jordan rift region based on speleothems from Zalmon Cave, Israel. In The Hebrew University of Jerusalem.

Kolska Horwitz, L. R., \& Hongo, H. (2008). Putting the meat back on old bones. a reassessment of Middle Palaeolithic fauna from Amud Cave (Israel). MOM Éditions, 49, 45-64.

Krakovsky, M. (2017). Decision making process and technology: Is there a "traditional" operational sequence? A case study of Levallois points from Amud Cave. The Hebrew University of Jerusalem.

Kreutzer, S., Martin, L., Guérin, G., Tribolo, C., Selva, P., \& Mercier, N. (2018). Environmental dose rate determination using a passive dosimeter: techniques and workflow for $\alpha$-A12O3:C chips. Geochronometria, 45, 56-67. https://doi.org/10.1515/geochr-2015-0086. 
Langgut, D., Almogi-Labin, A., Bar-Matthews, M., Pickarski, N., \& Weinstein-Evron, M. (2018). Evidence for a humid interval at $\sim 56-44 \mathrm{ka}$ in the Levant and its potential link to modern humans dispersal out of Africa. Journal of Human Evolution, 124, 75-90. https://doi.org/10.1016/J.JHEVOL.2018.08.002.

Langgut, D., Almogi-Labin, A., Bar-Matthews, M., \& Weinstein-Evron, M. (2011). Vegetation and climate changes in the South Eastern Mediterranean during the last glacial-interglacial cycle (86 ka): new marine pollen record. Quaternary Science Reviews, 30, 3960-3972. https://doi.org/10.1016/J. QUASCIREV.2011.10.016.

Lev, E., Kislev, M. E., \& Bar-Yosef, O. (2005). Mousterian vegetal food in Kebara Cave, Mt. Carmel. Journal of Archaeological Science, 32, 475-484. https://doi.org/10.1016/J.JAS.2004.11.006.

Madella, M., Alexandre, A., \& Ball, T. (2005). International code for phytoliths nomenclature 1.0. Annals of Botany, 96, 253-260.

Madella, M., Jones, M. K., Goldberg, P., Goren, Y., \& Hovers, E. (2002). The exploitation of plant resources by Neanderthals in Amud Cave (Israel): the evidence from phytolith studies. Journal of Archaeological Science, 29, 703-719.

Mallol, C., Cabanes, D., \& Baena, J. (2010). Microstratigraphy and diagenesis at the upper Pleistocene site of Esquilleu Cave (Cantabria, Spain). Quaternary International, 214, 70-81. https://doi.org/10.1016/J. QUAINT.2009.10.018.

Matmon, A., Enzel, Y., Zilberman, E., \& Heimann, A. (1999). Late Pliocene and Pleistocene reversal of drainage systems in northern Israel: tectonic implications. Geomorphology, 28, 43-59. https://doi. org/10.1016/S0169-555X(98)00097-X.

Mejdahl, V. (1979). Thermoluminescence dating: beta dose attenuation in quartz grains. Archaeometry, 21, 61-72. https://doi.org/10.1111/j.1475-4754.1979.tb00241.x.

Miller, C. E., Mentzer, S. M., Berthold, C., Leach, P., Ligouis, B., Tribolo, C., Parkington, J., \& Porraz, G. (2016). Site-formation processes at Elands Bay Cave, South Africa. Southern African Humanities, 29, 69-128.

Mulholland, S.C., Rapp, G.J. (1992a). Phytolith systematics: an introduction, in: Mulholland, S.C., Rapp, G.J. (Eds.), Phytolith systematics: emerging issues. Plenum Press, New-York - London, pp. 1-13.

Mulholland, S. C., \& Rapp, G. J. (1992b). A morphological classification of grass silica-bodies. In Phytolith systematics (pp. 65-89). Boston, MA: Springer US. https://doi.org/10.1007/978-1-4899-1155-1_4.

Murphy, C.P., 1986. Thin section preparation of soils and sediments.

Murray, A. S., \& Wintle, A. G. (2000). Luminescence dating of quartz using an improved single-aliquot regenerativedose protocol. Radiation Measurements, 32, 57-73. https://doi.org/10.1016/S1350-4487(99)00253-X.

Orbach, M., \& Yeshurun, R. (2019). The hunters or the hunters: human and hyena prey choice divergence in the Late Pleistocene Levant. Journal of Human Evolution. https://doi.org/10.1016/J. JHEVOL.2019.01.005.

Piperno, D. R. (2006). Phytoliths: a comprehensive guide for archaeologists and paleoecologists. Lanham, MD: Altamira Press.

Rabinovich, R., \& Hovers, E. (2004). Faunal analysis from Amud Cave: preliminary results and interpretations. International Journal of Osteoarchaeology, 14, 287-306. https://doi.org/10.1002/oa.762.

Rak, Y., Kimbel, W. H., \& Hovers, E. (1994). A Neandertal infant from Amud Cave, Israel. Journal of Human Evolution, 26, 313-324. https://doi.org/10.1006/JHEV.1994.1019.

Richards, D. A., \& Dorale, J. A. (2003). Uranium-series chronology and environmental applications of speleothems. Reviews in Mineralogy and Geochemistry, 52, 407-460. https://doi.org/10.2113/0520407.

Richter, D., Richter, A., \& Dornich, K. (2015). Lexsyg smart - a luminescence detection system for dosimetry, material research and dating application. Geochronometria, 42, 202-209. https://doi. org/10.1515/geochr-2015-0022.

Rink, W. J., Schwarcz, H. P., Lee, H. K., Rees-Jones, J., Rabinovich, R., \& Hovers, E. (2001). Electron spin resonance (ESR) and thermal ionization mass spectrometric (TIMS)230Th/234U dating of teeth in Middle Paleolithic layers at Amud Cave, Israel. Geoarchaeology, 16, 701-717. https://doi.org/10.1002/gea.1017.

Rosen, A. M. (2003). Middle Paleolithic plant exploitation: the microbotanical evidence. In D. O. Henry (Ed.), Neanderthals in the Levant: behavioral organization and the beginnings of human modernity. Continuum (pp. 156-171). London.

Shahack-Gross, R., Ayalon, A., Goldberg, P., Goren, Y., Ofek, B., Rabinovich, R., \& Hovers, E. (2008). Formation processes of cemented features in karstic cave sites revealed using stable oxygen and carbon isotopic analyses: a case study at middle paleolithic Amud Cave, Israel. Geoarchaeology, 23, 43-62.

Shahack-Gross, R., Berna, F., Karkanas, P., \& Weiner, S. (2004). Bat guano and preservation of archaeological remains in cave sites. Journal of Archaeological Science, 31, 1259-1272.

Shimelmitz, R., Friesem, D. E., Clark, J. L., Groman-Yaroslavski, I., Weissbrod, L., Porat, N., \& Kandel, A. W. (2018). The Upper Paleolithic and Epipaleolithic of Sefunim Cave, Israel. Quaternary International, 464, 106-125. https://doi.org/10.1016/j.quaint.2017.05.039. 
Stiner, M. C., Kuhn, S. L., Surovell, T. A., Goldberg, P., Meignen, L., Weiner, S., \& Bar-Yosef, O. (2001). Bone preservation in Hayonim Cave (Israel): a macroscopic and mineralogical study. Journal of Archaeological Science, 28, 643-659. https://doi.org/10.1006/jasc.2000.0634.

Stoops, G. (2003). Guidelines for analysis and description of soil and regolith thin sections., Guidelines for analysis and description of soil and regolith thin sections. Madison, WI: Soil Science Society of America Inc.

Suzuki, H., \& Takai, F. (1970). The Amud man and his cave site. Tokyo: Academic Press of Japan.

Torfstein, A., Goldstein, S. L., Stein, M., \& Enzel, Y. (2013). Impacts of abrupt climate changes in the Levant from last glacial Dead Sea levels. Quaternary Science Reviews, 69, 1-7. https://doi.org/10.1016/J. QUASCIREV.2013.02.015.

Trinkaus, E. (1987). The Upper Pleistocene human molar from Me'arat Shovakh (Mugharet esh-Shubbabiq), Israel. Paléorient. https://doi.org/10.2307/41492236.

Turville-Petre, F. (1927). Researches in prehistoric Galilee 1925-1926. London: British School of Archaeology in Jerusalem.

Twiss, P. C. (1992). Predicted world distribution of C3 and C4 grass phytoliths. In Phytolith systematics (pp. 113-128). Boston, MA: Springer US. https://doi.org/10.1007/978-1-4899-1155-1_6.

Twiss, P. C., Suess, E., \& Smith, R. M. (1969). Morphological classification of grass phytoliths1. Soil Science Society of America Journal, 33, 109. https://doi.org/10.2136/sssaj1969.03615995003300010030x.

Ullman, M., Hovers, E., Goren-Inbar, N., Frumkin, A. (2013). Levantine cave dwellers: geographic and environmental aspects of early humans use of caves: a case study from Wadi Amud, northern Israel, in: Filippi, M., Bosák, P. (Eds.), Proceedings of 16th international congress of speleology volume 1. Brno, Czech Republic, pp. 169-174.

Valladas, H., Mercier, N., Froget, L., Hovers, E., Joron, J.-L., Kimbel, W. H., \& Rak, Y. (1999). TL dates for the Neanderthal site of the Amud Cave, Israel. Journal of Archaeological Science, 26, 259-268. https://doi.org/10.1006/JASC.1998.0334.

Wadley, L., Sievers, C., Bamford, M., Goldberg, P., Berna, F., Miller, C., (2011). Middle stone age bedding construction and settlement patterns at Sibudu, South Africa. Science (80-. ). 334, 1388-1391. https://doi. org/10.1126/science.1213317.

Weiner, S. (2010). Microarchaeology: beyond the visible archaeological record. Cambridge: Cambridge University Press.

Weiner, S., Goldberg, P., \& Bar-Yosef, O. (2002). Three-dimensional distribution of minerals in the sediments of Hayonim Cave, Israel: diagenetic processes and archaeological implications. Journal of Archaeological Science, 29, 1289-1308. https://doi.org/10.1006/jasc.2001.0790.

Weiner, S., Schiegl, S., Goldberg, P., \& Bar-Yosef, O. (1995). Mineral assemblages in Kebara and Hayonim caves, Israel - excavation strategies, bone preservation, and wood ash remnants. Israel Journal of Chemistry, 35, 143-154.

Weinstein-Evron, M., Tsatskin, A., Weiner, S., Shahack-Gross, R., Frumkin, A., Yeshurun, R., \& Zaidner, Y. (2012). A window into Early Middle Paleolithic human occupational layers: Misliya Cave, Mount Carmel, Israel. PaleoAnthropology, 202-228. https://doi.org/10.4207/PA.2012.ART75.

Zeigen, C., Shaar, R., Ebert, Y., Hovers, E. (2019) Archaeomagnetism of burnt cherts and hearths from Middle Palaeolithic Amud Cave, Israel: Tools for reconstructing site formations processes and occupation history. Journal of Archaeological Science 107:71-86

Zohary, M. (1973). Geobotanical foundations of the Middle East. Stuttgart: Gustav Fischer Verlag.

Publisher's Note Springer Nature remains neutral with regard to jurisdictional claims in published maps and institutional affiliations.

\section{Affiliations}

\section{David E. Friesem ${ }^{1,2} \cdot$ Ariel Malinsky-Buller ${ }^{3} \cdot$ Ravid Ekshtain $^{4} \cdot$ Shira Gur-Arieh $^{5,6}$. Anton Vaks ${ }^{7} \cdot$ Norbert Mercier $^{8} \cdot$ Maïlys Richard $^{8} \cdot$ Gilles Guérin $^{9} \cdot$ Hélène Valladas $^{9}$ • François Auger $^{10}$. Erella Hovers ${ }^{4,11}$}

1 McDonald Institute for Archaeological Research, University of Cambridge, Downing Street, Cambridge CB2 3ER, UK

2 Zinman Institute of Archaeology, University of Haifa, 199 Aba-Hushi Avenue, 3498838 Haifa, Israel 
3 MONREPOS, Archaeological Research Centre and Museum for Human Behavioural Evolution, Schloss Monrepos, 56567 Neuwied, Germany

4 The Institute of Archaeology, The Hebrew University of Jerusalem, Mt. Scopus, 91905 Jerusalem, Israel

5 Harvest Project, Faculty of Archaeology, Leiden University, Einsteinweg 2, 2333 CC Leiden, The Netherlands

6 Department of Humanities, CaSEs Research Group, Universitat Pompeu Fabra, Barcelona, Spain

7 Geological Survey of Israel, 32 Yeshayahu Leibowitz St, 9371234 Jerusalem, Israel

8 Institut de Recherche sur les Archéomatériaux, UMR 5060 CNRS, Université Bordeaux Montaigne, Pessac, France

9 Laboratoire des Sciences du Climat et de l'Environnement, IPSL, UMR CEA-CNRS-UVSQ, avenue de la Terrasse, 91190 Gif/Yvette, France

10 Laboratoire SCL de Bordeaux, 3 Avenue du Dr Albert Schweitzer, 33600 Pessac, France

11 Institute of Human Origins, Arizona State University, Tempe, AZ, USA 